\title{
Virumaa rahvapillid
}

\author{
Igor Tõnurist
}

Teesid: Artikkel käsitleb ajaloolise Virumaa eesti talurahva traditsioonilisi muusikariistu ja helitekitamise vahendeid ning nende kasutamist eeskätt 19. ja 20. sajandil kogutud andmete põhjal.

Võib väita, et Virumaa rahvapillimängukultuur on osa ühtsest suuremast Põhja-Eesti rahvamuusika-alasest areaalist, mis hõlmab Harju-, Järva- ja Virumaad. Selle areaali rahvamuusikalise eripära kujundajaks on kahtlema algselt olnud põhjaeestiline regilaul, kuid iseloomulik on ka suhteliselt ühtlane traditsiooniliste muusikariistade valik. Virumaa kohalik eripära tuleb esile vaid mõne nähtuse osas. Mainime siinkohas nt piibari nimelist pajukoorest vilepilliliiki ja uuema kandle nimetusi simmel/tsimmel/simbel. Mõneti kerkib pillide valiku ja nende nimetuste, samuti repertuaari poolest esile nn Iisaku poluvertsikute lokaalne rahvapillimängutraditsioon, milles on segunenud vene ja eesti nähtused (sh nt pillinimetused kannel=kusli, parmupill vargan, vilepill dutka, trumm puuben). Omaette selge etnilise värvinguga pillimängutraditsiooni poolest eristusid Virumaal kahtlemata veel Peipsi põhjaranniku ja Narva jõe äärsed vene külad, kuid sealsed rahvapillid on seni veel uurimata ja jäävad antud ülevaatest välja. Virumaa põhjarannikul esines ka mõningaid ühisjooni soome rahvapilli- ja rahvatantsutraditsiooniga (mõjutused tantsuviiside repertuaaris, samuti viiulimängus jms), Narva jõe alamjooksul esines kokkupuuteid sealsete isuritest karjuste pillidega (nt karjapasun truba).

Artiklis vaadeldakse Virumaa rahvapille lähtudes nende põhilistest pilliehituslikest näitajatest ning samuti pillide kasutussfääridest ja nende kajastumisest suulises rahvaloomingus. Virumaal fikseeritud rahvapille jagatakse liigiti nendel helitekitamise mooduse järgi puhkpillideks (nt vabad, klarnetilised ja trompetilised aerofonid), keelpillideks (kordofonideks) ning idiofonideks ja membranofonideks.

Märksõnad: aerofonid, idiofonid, Iisaku poluvertsikud, kordofonid, membranofonid, rahvapillid, Virumaa

Järgnevas ülevaates käsitletakse ajaloolise Virumaa eesti talurahva traditsioonilisi muusikariistu ja helitekitamise vahendeid eeskätt 19. ja 20. sajandil kogutud materjali põhjal. 
Kuigi üksikasjalik teaduslik uurimus Virumaa rahvapillidest seni puudub, võib laias laastus väita, et Virumaa rahvapillimängukultuur on osa ühtsest suuremast, Põhja-Eesti kolme maakonda - Harju-, Järva- ja Virumaad hõlmavast rahvamuusika-alasest kultuuriareaalist. Kui üldiselt on selle regiooni rahvamuusikalise eripära kujundajaks peetud eeskätt põhjaeestilist regivärsilist rahvalaulu, siis Virumaal läbi aegade kasutatud rahvapillide valiku osas kohalik eripära nii selgelt esile ei tule.

Üksikuid eripäraseid nähtusi Virumaal siiski esines. Nt mängiti puukoorest vilepille pea kõikjal Eestis, kuid piibariks kutsuti pikki koorest vilepille vaid Virumaa mõnes kihelkonnas (lõunaeestiline piipar tähendas hoopis karjapasunat!). Mitmekesisust lisas kohalikule pillikultuurile virulaste lävimine naaberrahvastega, kelle esindajad elasid vahetult Virumaa naabruses ning ka Virumaa eestlaste endi keskel. Narva jõe piirkonnas ja Peipsi põhjarannikul suheldi sajandeid vadjalaste, isurite ja venelastega. Mainitud etnilistest rühmadest kujunes eestlastega segunedes omapärane luteriusku nn Iisaku poluvertsikute kultuur, mis väljendus nt kas või rahvapillide terminoloogias (kannel ja kusli, vargan, dutka jt) või eri kandletüüpides. Virumaa piiridesse jäid ka puhtvene elanikkonnaga külad piki Peipsi põhjarannikut ja Narva jõge. Paraku on sealsete venelaste vanadest rahvapillidest teada väga vähe, rääkimata eriuurimustest nende rahvamuusika ja -pillide kohta. Kuid just nende vene asukate kaudu ulatus näiteks Virumaa Peipsi järve äärsetesse küladesse vene päritolu roopill sarvest kõlaotsikuga - žaleika. Praeguse Eesti alal mängisid samasugust pilli ehk sarvõpilli vaid setud.

Soome lahe äärsetesse eesti rannaküladesse ulatusid ka mõned soome päritolu nähtused, näiteks mitmed tantsud ja nendega seotud pilliviisid (nt Kupparimuori, Kiigari-kaagari). Põhiliste muusikariistade valik oli Soome lahe põhja- ja lõunakaldal enam-vähem ühesugune. Tõsi küll, soomlased ei tarvitanud torupilli nii palju kui eestlased, ja on ka andmeid pärisorjuse eest Soome pakku läinud eesti torupillimeeste tegevusest Lõuna-Soome maapiirkondades (Leisiö \& Tainio 1988: 9). Kas need torupillimängijad pärinesid otse Virumaalt, pole küll teada, aga võimalik see oli, kui pidada silmas soome ja eesti randlaste kauaaegseid sõbrasuhteid.

Rakveres Virumaa Muuseumis (SA Virumaa Muuseumid koosseisus asuva endise Virumaa Muuseumi kogu) on tallel kaks muusikariista, mis on ilmselt isuri algupära - vilepill ja lühike pasun (VM 139, E 11 ja VM 137, E 10) Mõlemad pillid on viie sõrmeavaga ning mähitud kasetohuribaga, mis on eesti vilepillidele võõras võte, samuti on eestlastele võõraks jäänud lühikesed, sõrmeavadega varustatud karjapasunad - trubad. Tohuga mähitud pillid on aga olnud iseloomulikud just vahetult Narva jõe taga elavatele isuritest karjustele 
(Veneküla, Saarküla), kes on 20. sajandi alguses oma osava pasunamänguga osalenud muuseas ka Narva-Jõesuu kuurordi puhkajate lõbustamises.

Vaatleme nüüd lähemalt, milliseid muusikariistu kasutas Virumaa eesti maarahvas. Teeme seda traditsioonikandjate endi kirjelduste abil, olid nad siis pilli valmistajad, mängijad või kuulajad, olgu tegemist kirjapanekuga mäluasutuses, siinkirjutaja isiklikus arhiivis või väljavõttega mõnest trükisest.

Muusikariistu võib käsitleda lähtudes esiteks kas pilli ehitusest ja helitekitamise moodusest (organoloogiline aspekt) või siis pillide kasutussfääridest, pillide funktsionaalsusest (nt laste-, karja-, signaal-, tavandi-, tantsu- jms pillid). Organoloogilise lähenemise puhul on oht klammerduda spetsiifilistesse pilliehituslikesse üksikasjadesse. Teise, nn funktsionaalse lähenemise puhul, mis ju omaette võetuna on üsna huvitav aspekt, võib jällegi kaduda teatud üksiku muusikariista ehituslik eripära. Loetavuse huvides on alljärgnevalt mõlemad aspektid ühildatud, mis aga tingib mõningaid kordusi tekstis. Ühtlasi on kaasajastatud arhiiviteadete kirjaviisi ning veidi lihtsustatud ka Eesti Keele Instituudi murdetekstide transkriptsiooni.

\section{Rahvapärased puhkpillid (aerofonid)}

Virumaal on läbi aegade mängitud nn vabadel aerofonidel (puuleht, kasetoht jms), samuti on tarvitatud mitmesuguseid flöödilisi (vilepillid), klarnetilisi (roopill, torupill) ja trompetilisi puhkpille (pasunad, sikusarv).

Vabad aerofonid on pillid, mille puhul pilli korpus ei piira õhusammast. Tuntuimad neist on mitmesugused puulehed või kasetohu riba, mida mängiti neid suu ette asetades ja servale puhudes. Lehepilliks (paiguti lehtpill) kõlbasid hästi haavalehed (Tudulinnas lõigati siis haavalehe tipulised servad sirgeks ja keerati lehe äär kahekorra); pajulehte ja muid sobivaid puulehti võis samuti puhumiseks kasutada.

Kahe pöidla vahele asetatud rohuliblega sai puhuda suvel. Selle pilli edasiarendus oli rohulible pingestamine kahe puuklotsi vahel (uulepill Kadrina khk Tõdva-Kõnnus). Rahvaluulekoguja Karl Voldemar Rosenstrauch iseloomustas neid mängumooduseid 1894. aastal Väike-Maarja ja Kadrina kogumisretkedel nõnda:

Oli üks laste kõige lõbusam suupill. Tuli kevade, lõi ta rohulehed ja sellega ka suupilli. Selle suupilli tegemiseks kõlbas lepapulk ja oras rohu leht. Kui aga Ei olnud aega niisugust teha, siis pandi leht kahe pöidla vahele ja puhuti - hüüdis niisama kui puust pill. Kes juba suurem oli, 
võttis kõva haava lehe, keeras ta suus natukene kahekorra ja mängis siis tantsu tükkid välja kui hülge magu (torupilli) ei olnud. (H 17, 446 (104).)

Simuna kandis Kissa külas mängiti 1923.-1925. aastate paiku simmanil (ka: säru) lehepilli teistele pillidele kaasa ja siis simmanil lasi mõni päris ilusasti ööbikut vahele (autori üleskirjutus Haljalas 1973. aastal Leo Kaljuveelt, 72 a, pärit Simunast).

\section{Flöödilised puhkpillid - vilepillid}

Näib, et Virumaal eksisteeris kunagi üsna arenenud ja eri instrumentide poolest vaheldusrikas vilepillikultuur, mis tänapäeval elab edasi vaid tagasihoidlikus laste pajuvilede tegemises.

Samas on aga Ruuben Kesleri - Jõhvi kihelkonna Vasavere külas elanud ja 1938. aastal Riigi Ringhäälingus heliplaadile mänginud pillimehe heatujuline “Taavetipolka” saanud vaat et vilepillimängijaist pärimusmuusikute meelislooks! Temalt pärineb ka pärimusmuusikute poolt tihti tsiteeritav ütlus, mille tol ajal märkis üles August Pulst: Kui põllust aega saan, kohe pill kätte, teeb meele rõõmsaks ja keha kergeks (vrd Pulst: 7).

Suurepäraseid erinevate vilepillide ja karjapasunate tegemise kirjeldusi on helilindistatud veel 1978. aastal Simuna kihelkonna Raja külas elanud Heinrich Kasemetsalt (68 a) ja Eduard Suumanilt (60 a) Metskülast (RKM, Mgn. II 100; Mgn. II 3096-3099).

Pikem sisukas ülevaade Kadrina kandi vilepillidest on pärit taas 1894. aastast V. Rosenstrauchi sulest. See kirjeldus leiab toetusainest mujaltki Eestist. Ta kirjutas:

Vaevalt oli kevade jõudnud ja müristamine puu koored lahti löönud, kui vilede tegemine poisikeste hulgas hakkas. Igaüks katsus aga kõige esimene olla, et teine teda ära petta ei saanud. Selleks leigati üksluine paju pulk, kellel oksi ei olnud, leigati ots suu järele, tehti silm peale üks neljakandiline augukene, keerati siis koor pealt lahti, tõmmati pulk välja ja leigati ainult veike prunt suu augu otsa. Prundil leigati pealt natukene ära ja pandi siis vile sisse. Tagumise otsa peale leigati siis veel sormised - veikekesed augukesed ja siis hakkas mängimine. Kes õppind mängija oli, mängis kohe tantsu tükkid välja. Vilesid oli mittu seltsi. Päris vile, kilk - õige peenikene ja heleda häälega, ja vene vile. Vene vile oli isemoodi. (H III 17, 430/1 (90).)

Niisiis tunti mitut liiki vilesid. Käsikirjas oleval joonisel on kujutatudki eriline puukoorest vilepill, mida ei puhutud mitte otsast, nagu tavalist vilepilli, vaid 


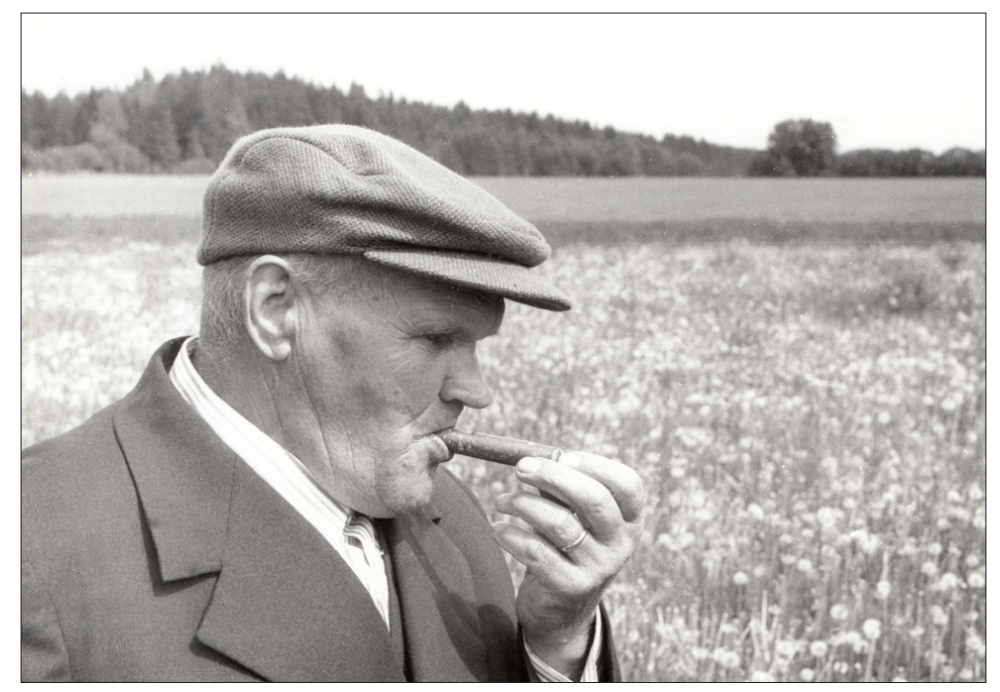

Foto 1. Heinrich Kasemets omavalmistatud pajupilliga. Simuna khk, Raja k. Mart Jallai foto, 1978. ERA, Foto 12268.

külje pealt, nagu üldtuntud kontsertflööti. Veidi koonusja pillitoru laiemasse ülemisse otsa oli paigutatud prunt ehk pea, sellest edasi oli toru peale märgitud puhumise auk, veel allapoole asus vileaken ehk silm. Pilli jätkuks oli lihtsalt tühi koor vile (H III 17, 430/1 (90)).

Iisaku kihelkonna Vaikla külas nimetati puukoorest (vahel ka isegi vasktorust tehtud) vilepilli suupill. Suupillil olnud kuus mänguava peal ning seda mängitud kuue sõrmega (KKI 20, 572 (85), (1955)).

Simuna kihelkonna Raja külas nimetatud mängimist sõrmiliste löömiseks, lepakoorest vilet tehes lausuti koort lahti koputades: Hele, hele, minu vile (RKM, Mgn. II 309813 ja 4b).

Eriline puukoorest vilepilliliik - piibar. Vene vileks nimetatud pajukoorest vilepill on Virumaal üldse huvitav nähtus, sest peale ilmselt selle küljelt puhutava vilepillitüübi erilisusele viitava vene vile nimetuse kasutati Virumaal mitmel pool sagedamini veel teistki nimetust - piibar, piibarpill, piipar (Viru-Nigula, Lüganuse, Jõhvi, Haljala, Viru-Jaagupi, Väike-Maarja). Olemasolevad kirjeldused rõhutavad, et piibar oli tehtud pikast puukooretorust ja oli ikka külje pealt puhutav: Minaki ise karjas käisin, siis ôli piiparpill. Nii pikk (-80 sm), seta puhusit siis külje päält. Tõised pillid õlid ikke õtsast puhu$d a$ (EKI murdekartoteek: 48, Lüganuse). Kahel teisel Eesti Keele Instituudi murdekartoteegis oleval Lüganuselt pärit piibarpilli sedelil on toonitatud, et piibar pilli puhutta keskelt. Mujal Eestis pole selline pill, mida tuli paio kuorest 


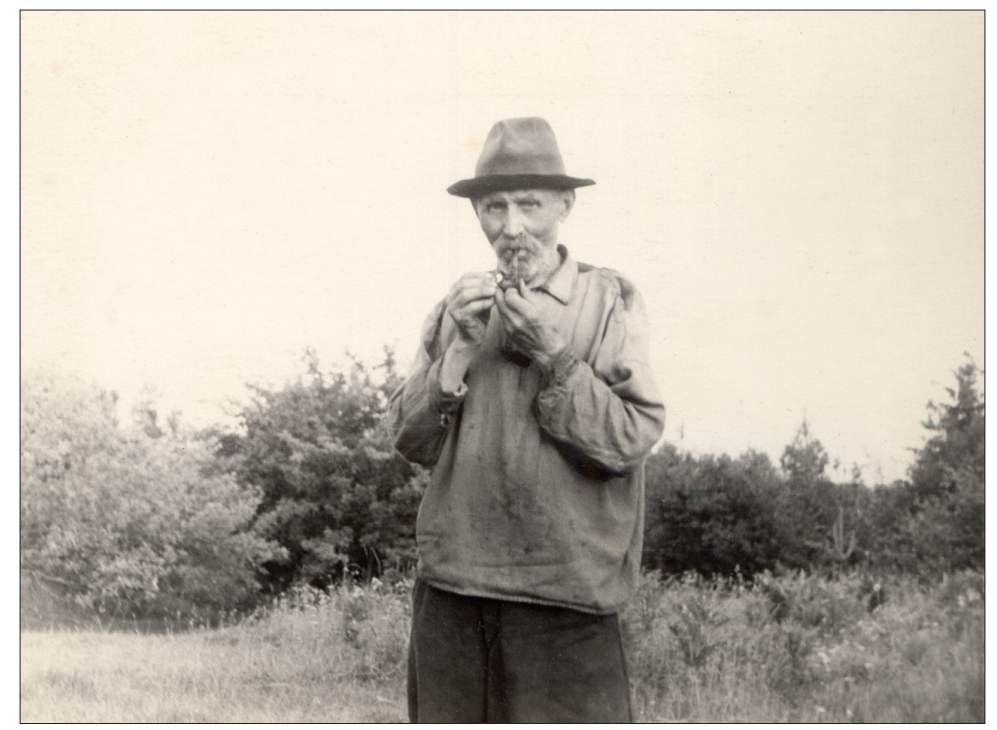

Foto 2. Taavet Murumäe mängib vilepilli. Iisaku khk, Vaikla $k$. Richard Viidalepa foto, 1955. KKI 20, 685.

väänättä ja küljelt puhuda, laiemalt tuntud (on vaid paar mainingut) - seega on kirjeldatud piibarpill eeskätt Virumaale omane vilepilliliik.

Laskumata arutlustesse selle pilli päritolust, tuleb terminoloogilise segaduse ärahoidmiseks märkida, et Kagu-Eestis on kõlalt lähedast nimetust piibar, piipar kandnud ainult puukoorest keeratud karjapasun, st sealne piibar on hoopis teistsugune puhkpill. Soome keeles tähendas piipari pillimängijat ja ka pilli. Sõna piibar päritolu vaadelnud Ants Viires osutab, et selle termini eesti vastele on pakutud aluseks keskalamsaksa samatähenduslikku nimetust pīper (Viires 2003: 362).

Männikasvust vilepill. Kestvamad vilepillid tehti noorest tollijämedusest männikasvust, mille südamik puumahlade liikumise aegu välja pöörati ning saadi nõnda vajalik toru (siit ka haruldasem pöörpilli nimekuju). Järgnes samasuguse vileseadeldise tegemine nagu pajupilligi puhul, puhuti otsast. Kadrina kihelkonna Tõdva-Kõnnu külas nimetati sellist vilepilli 1938. aasta paiku jorupilliks ja sellel olnud peal vaid kaks mänguava, nagu ka Viru-Nigula vilepillil. Iisaku poluvertsikute juures nimetati 12 tolli pikkusest männikasvust tehtud ja kuue mänguavaga vilepilli venepäraselt dudka, dudotška (KKI 20, 576 (97), (1955)).

Kahe poolega vilepill. See on haruldane puukoorest tehtud vilepill, millele pole naabermaadest paralleele leitud. Eesti alalt on teateid siit-sealt Põhja-Ees- 
tist, nt Kuusalust (Kõnnus pajupill kahe otsaga) ja Avinurmest (kahe poolega vene pill). Sellel vilel oli keskel puhumisauk, millest õhk kahele poole juhiti. Vile üks pool oli pikem kui teine ja nii sai mängida kahehäälseid kooskõlasid. Ajalooliselt Virumaalt on niisuguse pilli kohta vaid üks üleskirjutus, mis tõendab, et sellist viletüüpi siin vanasti tunti.

1928. aasta paiku teinud endale sellise pilli pajukoorest Vaivara kihelkonna Puhkova külas noor poiss Päite Villem. Keskelt puhutaval umbes $30 \mathrm{~cm}$ pikkusel vilepillil olnud üks ots veidi pikem kui teine ja sellel olnud vist sõrmilised (sõrmeavad) peal. Vile teinud puhumisel korraga kahte häält. Jutustaja meenutas ka, et mängija liigutanud veel lahtise pilliotsa ees sõrmega, kuid milleks ta seda tegi, ta enam ei mäletanud. (Autori üleskirjutus Puhkovast pärit eakalt väliseestlaselt Mart Kiiverilt Rootsis, 1979.)

Vilepill oli mängijatele nii meelelahutuseks kui ka karjuse töövahendiks.

Vanavarakoguja August Pulst kohtus 1908.-1910. aastate paiku Viru-Jaagupi mõisa u 70aastase karjuse Karja Jaakopiga, kes olnud kirgline vilepillimängija. A. Pulst kirjutas tema kohta, et pill hü̈̈dis tal lakkamatult nii söödamaadel karja juures, kui ka teel koju tulles, metsa minnes. Kord lubanud Jaakop oma pilli A. Pulstile, kuid tuli järgmisel päeval järele - loomad olevat rahutud ilma pillita (Pulst: 11).

Mõningaid Virumaalt pärit ja ERA kogudes säilitatavaid vilepilliviise Lüganuselt (1915) ja Kadrinast (1910 ja 1914) on avaldatud (vt: Tampere 1975: 73; Rüütel 1992: 230).

Peibutusviled. Jahimehed on kütitavate lindude ja loomade ligimeelitamiseks kasutanud mitmesuguseid helivahendeid. Tuntuimad neist olid laanepüüde jahtimiseks ette nähtud viled ehk nn pü̈üviled või püüpillid. Selline vile oli väike seest õones toruke, millel auk peal. Augu kohal oli torus kolmnurkne vahatükike, mida sai veidi liigutada ja sedaviisi vile häält korrigeerida. EKI murdekartoteegis on sõna pü̈̈pill seletusena tallel Lüganuselt pärit tekst:

Pü̈̈ pillit ja pü̈̈ vile, kelleka saap kutsuta juure. Metsä põõsa alle istut maha, akkat vilistämä, kuulep, siis akkab vasta tekemä. Pilli ruokust sai tehä, kukke sä̈̈re kontist ja... teki pü̈̈ äält kõhe.

Virumaa jahinduse kirjelduses 1927. aastast peamiselt Iisaku kihelkonnast on koguja Eduard Kääparin laanepüüde peibutamist vilega nimetanud pillitamiseks:

Pillitamist tarvitati püvede pü̈̈dmiseks. Sellejuures tegi kütt püve häält järele vastava pilli abil. Püved lendasid kaugelt pillitaja juure ja laskusid murule, kütile lähenedes. Imestanud lind ei aimanud 3-4 sammugi kaugusel hädaohtu ja sai küti saagiks. (ERM EA 13: 43; tsiteeritud: Loorits 2004: 351.) 
Jahivilede tegemise puhul oli tähtis ka teatud uskumusliku iseloomuga reeglitest kinni pidada. Nõnda arvatud, et kui pü̈̈ vilede tegemist alustada pühapäeval, siis olla need väga head (Simuna khk, 1888).

Maagiline vilepill. Peibutusvilede teemaga on seotud uskumus usside väljakutsumisest, sest selle, olgugi olemuselt maagilise tegevuse sooritamiseks kasutatakse juttudes ju konkreetseid jahimeeste peibutusvilesid (alati küll ei selgu, kas selleks oli vilepill või lihtsalt huultega vilistamine). Sellekohaseid teateid on Virumaalt Jõhvi ja Simuna kihelkonnast. Simunas on näiteks kuuldud, et mõni inimene kutsund ussi välja vilega ja arvatakse, et küllap see vile oli niisuke, mis järele aimas emase häält ja seega siis isased kokku meelitas (ERA II 12, 345 (46), (1928-1929)).

Folklorist Mare Kõiva on ühes uurimuses käsitlenud nn nõidkarjuseid, kes kutsusid välja hunte või usse ja ravisid inimesi. Ühe sellise nõidkarjuse Hundi Kustase kohta räägitud Jõhvi khk Ohakvere külas 1958. aastal, et tal "oli pärimuse järgi hundivile ja ussivile, kes suutis inimesele sisse läinud ussi välja meelitada, roosi arstida ja ka vitsavalu võtta. Seda vanapärast tarkust on sel sajandil vähesed targad vallanud" (Kõiva 1992: 130).

Paaniflöödi tüüpi vile. See putkevilena siin-seal Eestis tuntud ja eeskätt laste mänguasjade hulka kuulunud vilede liik tehti ülalt lahtisest heinputke torust, mille alumise otsa sulges looduslik sõlmekoht. Puhuti torusse lahtist otsa püsti vastu huuli hoides. 1973. aastal rääkis Simuna kihelkonna Käru külast pärit Meeta Üllaste (70aastane) autorile, et heinaajal tehtud tema lapsepõlves putkepille. Need olnud erineva pikkuse ja jämedusega, seesmise vatiga putk ei sobinud. Kodus hoitud putkevilesid vees, et need ära ei kuivaks. Isa Hansu juhendamisel tehtud lastega heinamaalt koju tulles marsitaktis mängides orkestrit. Mingit viisi siiski ei mängitud. Laste putkevile kohta on Virumaalt teateid veel ka Iisaku kihelkonna Roostoja kandist Mall Hiiemäelt (EKRK I 19, 354/5 (3), (1955)). Putkest tehti veel teinegi puhkpill ehk nn heinputke pill, millest lähemalt veidi allpool klarnetiliste pillide käsitluses.

Vile- ja lehepillide koosmängust. 19. sajandil Eesti küla- ja seltsielus levima hakanud puhk- või keelpilliorkestrite mäng andis külameestele mõnikord ideid ja eeskuju lihtsate pillide kokkusobitamiseks ja omamoodi uute "rahvapilliorkestrite" loomiseks. Kuivõrd tõsiseltvõetav oli selline koosmäng kunstiliselt tasemelt, pole teada, kuid huvitavaks faktiks Virumaa vilepillimängu ajaloos ta jääb.

1937. aastal kirjeldas Gustav Jürjev muusikaolusid Rakvere mail ning kirjutas muuhulgas järgmist:

Elus on üks kuulsamaid pillimängijaid Sõmmeru Kohalas Jäätma külas Hans Ups. Tema mängib viiulid ja käis oma õppetetud kooriga ümberkaudu koolitubades kontsertisi andmas. Kõigil olid omatehtud puust ja 
pajukoorest viled ja piibarid, kuhu hulka mõned puu lehed suus ööbiku ja teisi lindude laulu lasivad... Sikusarve Siim ja Torupilli Toomas ei ela enam, mängiti ka lõetsapilli, aga see oli suur patt. (ERA II 167, 603 (13).)

\section{Klarnetilised puhkpillid}

Rukkipill. Kõige lihtsamat klarneti tüüpi esindab pill, millel heli tekitab eriline keeleke, mis on lõigatud pilli torujasse kehasse või eraldi torukesena - nn piuguna juurde lisatud. Kadrina rukki pilli kohta on K. V. Rosenstrauch kirjutanud: Suve jõudmisega jõudis ka see aeg kätte, kus rukkis täieealiseks saab ja temast pilli võib teha. Sellele lisandub kirjeldus nelja mänguavaga (sõrmused ehk klahvid) varustatud rukkipillist, mille ülemine ots, mis suhu võetakse, jäetakse lõikamata jätkusõlmega kinniseks. Sellest kohast veidi allapoole on rukkikõrre sisse lõigatud piklik keeleke, mis puhumisel võnkuma hakkab ja häält tekitab (H III 17, 451 (108), (1895)). Samasuguse ehitusega pilli sai teha pilliroost, siis oli ta roopill.

Peipsiveere vene žaleika. Põhimõtteliselt on roopilliga sarnane Peipsi põhjakaldal Iisaku kihelkonna piiridesse jäävas eesti-vene elanikkonnaga Katase külas 1953. aastal fikseeritud venepärane sarvepill žaleika. Erinevalt tavalisest eesti roopillist koosneb see pill kolmest osast: pilliroost piugust, nelja mänguavaga torust ja selle otsa kinnitatud lehmasarvest. Žaleika on naabruses Pihkvamaal olnud eeskätt vene külakarjuste pilliks ja ka Katasel mängis seda külakarjusest noormees, kes olnud ema poolt koguni eestlane. Selle pilli esinemine Peipsi põhjarannikul

Foto 3. Villem Viirmann mängib sarvepilli. Simuna khk. Helmut Joonuksi foto, 1968. ERA, Foto 10165.

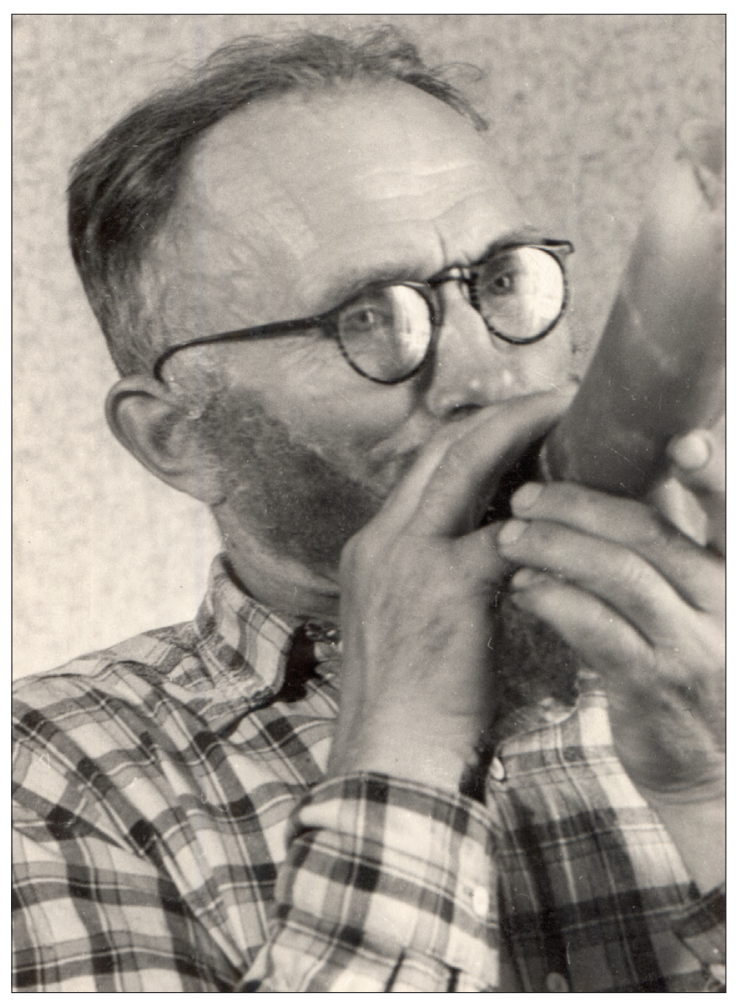


on üsna ootuspärane, kuna kohalik vene rahvakultuur on üldiselt jätkuks järve idakalda Oudova-Pihkva vene rahvakultuuri regioonile. Üks žaleikaga sarnane, kuid puust tehtud toru pill on fikseeritud haruldusena ka eestlasest karjusel Torma kihelkonna Võtikvere vallas ja täitsa omane on sarvõpill setudele (Tõnurist 2004: 88-90, vt ka joonis 3 ja 4).

Heinputke pill. Võnkuva pillikeha printsiibil häälitses Kadrina mail ka heinputke pill, mille kirjeldamisega V. Rosenstrauch jätkab eeltoodud rukkipilli kirjeldust:

Oli aga rukis kollaseks ja kõrred kõvaks jäenud, siis tuli heinaaeg [---]. Siis lõigati noorel heinputkel üks sõlmevahe ära, lõigati terava noa otsaga pikkuti üks pragu, ja hakati siis teinepoolt otsast puhuma. Hääl, mida see putk siis andis, oli väga ilus ja lõbus kuulda. (H III 17, 451 (107-108).)

Eestis on seda pilli (jänese)huigi, putkepilli jms nimetuste all tuntud mujalgi.

Torupill. Virumaa territooriumilt pärineb üks vanimaid eesti torupilli ja torupillimängija kujutisi. See on nimelt aastasse 1635 dateeritav pilt "Pulmasõit" Adam Oleariuse reisikirjeldusest (1996: 121). Sellest ajaliselt vanem torupillimängija on kujutatud Bernt Notke "Surmatantsus", kuid selle 15. sajandisse kuuluva teose inimtegelased (seda enam veel luukerena kujutatud torupillimees!) on n-ö etniliselt määramatud ja eri seisustest eurooplased, seevastu Ole-

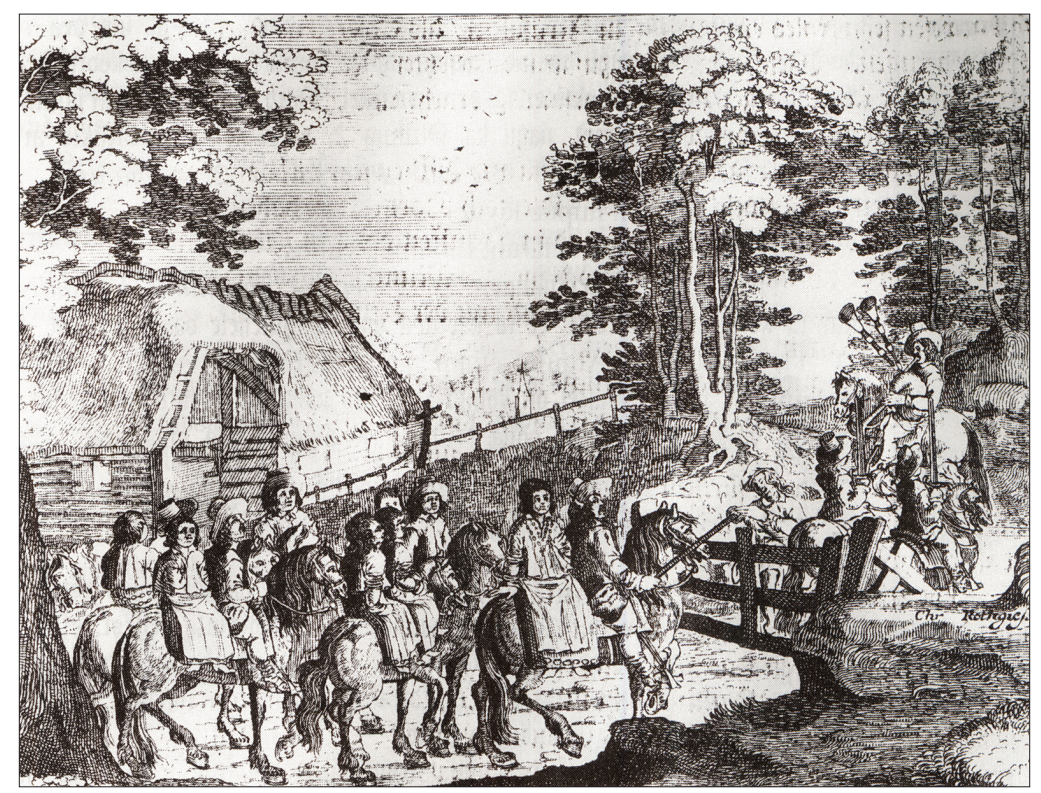

Foto 4. "Ees ratsutab torupillimees." Adam Oleariuse joonistus pulmakirjelduse juurde 17. sajandist. 
ariuse pildil on kujutatud kindalt Virumaa eesti talupoegi kusagil Viru-Nigula kandis. See tähendab, et ka pulmarongis ratsutav torupillimängija on ilmselt eestlane. Tal on käes suur, kahe püstise bassitoruga ja koonilise viisitoruga torupill. Bassitorude püstise asetusega torupilli mängimist pole hiljem Eesti alal fikseeritud, kuid see on päris tüüpiline Lääne-Euroopa maades (üldtuntuim sellistest pillidest on tänapäeval näiteks šoti torupill). Püstise bassitoruga on muide kujutatud ka "Surmatantsu" luukerest torupillimängija pill. Oleariuse pildil kujutatud rahvariiete ja tavandilise pulmastseeni eestilisus on eesti hilisema etnograafilise ja folkloorse ainestiku põhjal hästi kinnitatav, kuid torupilli mängimine esindab ilmselt mingit hiljemalt 19. ja 20. sajandi andmete põhjal eesti rahva seas käibelt ära jäänud mängumoodust. Kõik teadaolevad eesti torupillimängijad on hoidnud bassitoru(sid) all, käe otsas rippumas.

Rahvarõivaste järgi (käistega naised, tinanööpidega pikk-kuues mees) võib Põhja-Eestisse, sh eeldatavalt ka Virumaale, paigutada balti-saksa kunstniku Friedrich Ludwig von Maydelli (1795-1846) akvarelli "Torupillipuhuja" (avaldatud: Kirme 1986: tahvel VI). Kuid see torupill on kujutatud oskamatult ja eksitavalt (bassi- ja viisitorud on paigutatud tuulekotis valesti, viisitorusid on lausa kaks kõrvuti, mis tundub olevat võimatu).

Muid torupillimängijate pilte Virumaalt pole teada. Pole Eesti muuseumides ka täpselt ja kindlalt Virumaa kuuluvusega torupille (paari pilli virumaaline päritolu ERMi kogudes on küsitav, vt ERM A 296:29 ja ERM 16159).

Kohaliku Virumaa torupilli võib ilmselt taastada olemasolevate kirjelduste ja naabruses Harjumaal Kuusalu kihelkonna rannakülades lausa 20. sajandi algukümnenditeni kestnud torupillitraditsiooni põhjal. Viimaseid Viru torupillimehi mäletati veel isegi 20. sajandi keskpaiku, niisiis võib arvata, et nad tegutsesid 19. sajandi lõpuveerandil, mil see pill lõplikult aktiivsest kasutusest ära jäi. Üksikjuhtudel mängiti seda veidi kauemgi. Lüganusel Purtse-Liiva kõrtsis mängitud torupilli veel 1906. aasta paiku (ERA II 128, 127/8 (1)). Pillimees mänginud laua peal, tantsitud ümber. 1925. aastal kirja pandud mälestuste järgi tehti Haljalas torupilli tuulekott ehk lõots, mis tuli enne mängimist täis puhuda, harilikult hülgemaost, kui polnud, [siis] ka suurte loomade rakkust [põiest]. Õhku puhuti kotti läbi erilise torukese - suunaputi. Viisitoru - esimik oli viie [mängu]auguga, selle esimiku otsas, st tuulekoti sees, andis õhusurvel häält roost või hanesulest tehtud piuk - pill. Torupillil olnud kaks bassitoru (ERM EA 10: 305).

Toodud kirjeldus on üsna tüüpiline üldeestiline torupilli kirjeldus. Kuid lausa erakordne on 1925. aastast pärit teade Simuna kihelkonnast, kus torupilli mängitud kõrtsis veel umbes 1885. aasta paiku. Selle torupilli tuulekott oli nimelt ilvese nahast, millele jalad ja pää külge jäetud (ERM EA 10: 739). 
Jõhvi kihelkonna lõunaosas Edivere külas on A. Pulst 1938. aastal üles kirjutanud Maria Lulla (78 a) mälestuse umbes 60 aastat tagasi nähtud torupillist, mida koerad kartsid, sest see oli tehtud koeramaost, millel torud olnud küljes. Pillimees lõi kõrtsis kaikaga vastu magu. (Pulst: 872) Kuidas see kaikaga löömine tegelikult võis toimuda, jääb siiski selgusetuks. Samast Illuka ümbrusest on 1937. aastast olemas ka 87aastase Hindrik Õunapi seletus, mis eelmist teadet toetab: Torupill üürgas pulmas ühtepuhku. Sie õli kueramaost tehtud, sarved [mängutorud?] külles. Rahvas lasivad labajalavaltsi. Mehed vahest lasivad kükakille ka (ERA II 166, 346/7 (26)).

Ka Iisaku poluvertsikute seas on mängitud torupilli. Rahvaluulekoguja Alli Vetekaja kirjeldas seda nii, mainides veel mingit sia põiest pilli: Matuška vanamees mängis veel "tudkat" [muusikariist], seda puhus suu pial. Meie Taavet rääkis, et sie oli tehtud veikese koera vai kassi nahast ja täispuhutud. Aga võib-olla ka ta valetas (ES KT 173, Iisaku khk, 80-81). Pole kahtlust, et jutt on torupillist. Ka tudkale leiame seletuse. 1930. aastal kirjutas Karl Leichter Jõuga külas poluvertsikust Muri Peetrilt, et 65 aastat tagasi oli torupill ( $\partial y \partial a)$. Duda on muide üsna tavaline torupilli nimetus Valgevenes ja Ukrainas (Tõnurist 1985: 103-104), ka Lätis ja Leedus.

Torupillimängu kohta on mälestusi üle Virumaa. Eriti tihti mainitakse torupilli seoses tantsimisega pulmades ja kõrtsides, samuti talgutel ja mardiskäimise juures. Kuid kohalikke torupillilugusid on üles kirjutatud väga vähe, avaldatud on vaid üks Viru-Jaagupist Roela valla Tudu külast pärit torupillimehelt Gustav Alaverilt pärit lühike "Sõjalugu", mis on P. Penna poolt fikseeritud 1905. aastal (Tampere 1975: 81, nr 27; kaks samas avaldatud nn torupillilugu, nr 28 ja 29 on ette lauldud).

Kadrina kihelkonna põhjaosas Võhma külas mäletati 1938. aastal, et pulmas oli vanasti mängitud erilisi tavandilisi torupillilugusidki, nt noorpaari laudaistumise, pruudi põlle lappimise ja pruudi tantsitamise puhul. Siis oli ike torupil'lil ka lugu selle järele, ega ta siis iga tükki lüend (Lahemaa lugusid 1989: 197).

Jõhvi kihelkonna Rausvere külast on 1939. aastast kirjeldus, et

50 aastat tagasi olnud kuulus terves Jõhvi vallas [---] "Lutrus Mart". Tema õiget nime paljud ei teagi. Elas saunas, käis vallakorda, oli kuulus torupillimängija. Pühapäeva õhtuti mängis noortele. Talvel panid noored tema kelgule ja viisid 70aastase vanamehe endile pilli mängima. Eriti palju tööd oli mardipäeva ajal, kui sandid viisid "Mardi” endaga kaasa pillimängijaks. "Vallakorda" käies lõi Lutrus Mart alati torupilli hü̈̈dma, mille oli ise endale teinud. (ERA II 215, 291/2 (6).)

Järgmine teade on Lüganuse kihelkonnast: 
Püssi mõisas talgul torupill mängind. Varja külas old Pilli-Madis, old suur mängija. Teda on kutsutud pulmadesse ühtelugu. Pulmas on ikka ka torupilli järele tantsitud. Minu lell rääkis, et Pilli-Madis käind pulmades mängimas. (ERA II 128, 130/1 (1), (1936).)

Ajapikku hakkas torupill Eestis tantsupillina uuemate moepillide - viiuli ja lõõtspilli eest taanduma. On üksikuid teateid, nt Pärnumaalt, et vahel on torupilli mängitud kokku viiuliga. Sellist koosmängu tõendava huvitava fakti Virumaalt pani kirja rahvaluulekoguja Helmut Joonuks Simuna khk Kissa küla pulmakombestikku kirjeldades. 1947. aastal mäletas sealne elanik Juhan Rääk (76 a), et Vahest torupill ja viiul mängisid viel kokku (RKM II 15, 174 (1)).Toredal moel on soomlase vaatevinklist iseloomustatud virulaste torupilli ühes naljandis: Soomlane näinud Virus torupilli. Läinud koju, rääkind: "Oi pagan, seda Virulase pilli! Säkki süles ja aisad külles, ise nõnda ülbune perassa!” (D. Pruhl Haljalast, vt http://www.folklore.ee/rl/pubte/ee/vanad/eisen/ nali1/sisu.html)

\section{Trompetilised puhkpillid}

Nende muusikariistade puhul hakkab õhusammas võnkuma mängija enda pingutatud huulte abil. Tuntumad eesti maarahva (sealhulgas ka Virumaal kasutatud) trompetilised pillid olid puukoorest ja puidust eri pasunad ning sarv. Need olid tähtsad töö- ja signaalivahendid karjanduses, olles külakarjuste lahutamatud kaaslased, omamoodi ametisümbolid, mistõttu neid pille on nimetatud mõnikord ka karjapasunateks või -sarvedeks.

Pasunad. Karjapasunaid oli kahte liiki: lihtsamaid - lepakoorest tehtud, ja puust õõnestatud pasunad. Lepapasunaid kasutati talukarjades mõnes kohas veel kuni Teise maailmasõjani, puupasunad ja hiljem nende kõrvale ilmunud plekkpasunad kadusid tarvituselt koos küla ühiskarjade ja neid hoidnud külakarjuste institutsiooni kadumisega Eesti külas.

Lepakoore lindist pika tuutuna kokku keeratud pasun oli rohkem poisikeste mänguriist. See polnud kauakestev pill, sest kuivas kiiresti kokku ega kestnud tavaliselt üle ühe päeva. Et pasuna iga veidi pikendada, tuli see ööseks vette likku panna. Pilli laiem ots kinnitati haralise pulgaga, kitsamasse otsa püüti keerata koorest midagi väikese süvendi taolist, mis moodustas puhumist kergendava huuliku. Mõnikord tehti Kadrina kandis sinna lausa puust huulik: Peenemasse otsa leigeti veel üks veikene kaunis suure auguga puuprunt ja pandi peenemasse otsa, et ots kõvem suu järele oleks ja siis hakkas tuttav karjapasuna lugu (H III 17, 449/50 (107)). 


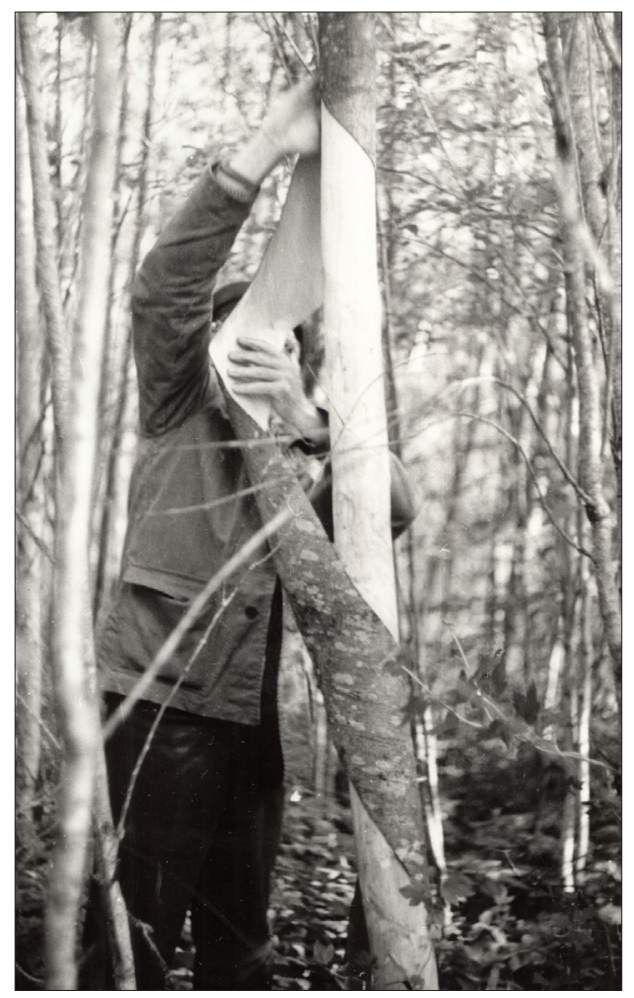

Foto 5. Lepa koorimine karjapasuna valmistamiseks. Simuna khk, Metsküla. Mart Jallai foto, 1978. ERA, Foto 12255.

Kadrina kihelkonna Tõdva-Kõnnu külas teinud üks karjapoiss 1930. aastate lõpus teistsuguse heliseadeldise ehk keele, mis valmistati lömastatud lepakoore tükist ja torgati pasuna ülemisse otsa - sinna puhudes hakkas n-ö oboe-tüüpi keel torus kärisema. Karjapoiss lõiganud lepatuutule isegi mitu mänguava peale, kuid nendest olnud vähe kasu (autori üleskirjutus 1972. a). 1973. aastal seletas 57aastane Leo Tubli autorile Viru-Nigula Vasta asunduses (end Nugeri), et oma lepapasuna ülemisse otsa on ta karjapoisipõlves pannud helitekitajaks pajupulgast tehtud torukese, millele oli piklik keeleke sisse lõigatud.

Et niisugune lepapasunamäng pole veel rahva mälust kustunud, tõestas 2005. aastal Iisaku laadal umbes 70aastane Jüri Kuusk (pärit Avinurmest), kes oli teinud rohkem kui meetri pikkuse lepapasuna, sellele mingi heliseadeldise otsa pannud ning puhus seda laadaliste lõbuks.

Külakarjusteks olid tavaliselt täiskasvanud mehed, kellele pikk pasun (Iisa$\mathrm{ku}$ poluvertsikute seas nimetati haavapuust pasunat ka truba) oli kohustuslikuks tööriistaks, millega külarahvale vajalikke signaale edasi anti. Nõnda äratati varahommikul perenaisi, hiljem kutsuti kari kogunemiskohta, karja hoides peletati pasunapuhumisega metsloomi ja rahustati oma karja, õhtul teatati puhumisega karja kojutulekust (Viru-Jaagupi khk kohta vt nt ERM EA 25: 185). Oli ilus iga omiku kuulata karjamehe pasunat ja lõuna ka ja vahel mängis õhtugi. Nü̈̈d see uus aeg on kõik karjaskäimised ära kadund, räägiti 1937. aastal Simuna Avanduse vallas (ERA II 149, 732 (1)); tsiteeritud Loorits 2001: 96 järgi). Rakke kandis räägiti sedagi, et Pasunaga anti märku, siis perenaised akkasid lehmi lüpsma (KKI 12, 233 (4), (1950)). 
Kus õitsilkäimise tava kauem säilis, seal on mõnikord märguandeks samuti pasunat puhutud. Viru-Nigulas Nugeri külas elanud 66aastane Jüri Veski meenutas 1940. aastal, et oli käinud õitsil veel 1888. aasta paiku:

Ikke sai enne metsas hõisata, et need, kes järele tulid, teadsid ka sinna tulla, kus esimesed olid. Pasun ikke ka oli, ise omatehtud pasun. Oli kaks kü̈̈nart pikk ja mõnel pikem. Siis ikke õhta, kui läksime, puhuti. See oli märguandmine, et ma lähen jo. (ERA II 287, 178 (1); tsiteeritud Loorits 2001: 201.)

Pikki karjapasunaid tehti Haljala, Viru-Nigula, Lüganuse ja Iisaku kihelkonna kirjapanekute järgi lepast, haavast, jämedast kuuse- või kadakajuurest, mis pikuti pooleks lõhestati, seest tühjaks õõnestati ja taas kokku pandi. Mõnikord mässiti puidule peale veel kasetohtu. Selline on näiteks Lüganuse kihelkonna Rääsa külast pärit $118 \mathrm{~cm}$ pikkune kadakajuurest karjapasun, mida säilitatakse Eesti Rahva Muuseumis (ERM 17518). Kaks Virumaalt pärit toredat kuusejuurest ja haavapuust pasunat on hoiul Eesti Teatri- ja Muusikamuuseumis. Need tegi A. Pulsti tellimisel 1938. aastal Haljala kihelkonna Vainupea külas Joosep Akker (79 a). Pärast Vainupea uute pasunate proovipuhumist ja pillide pildistamist kirjutas A. Pulst nukralt: Kas äsja kostnud pasunahelid

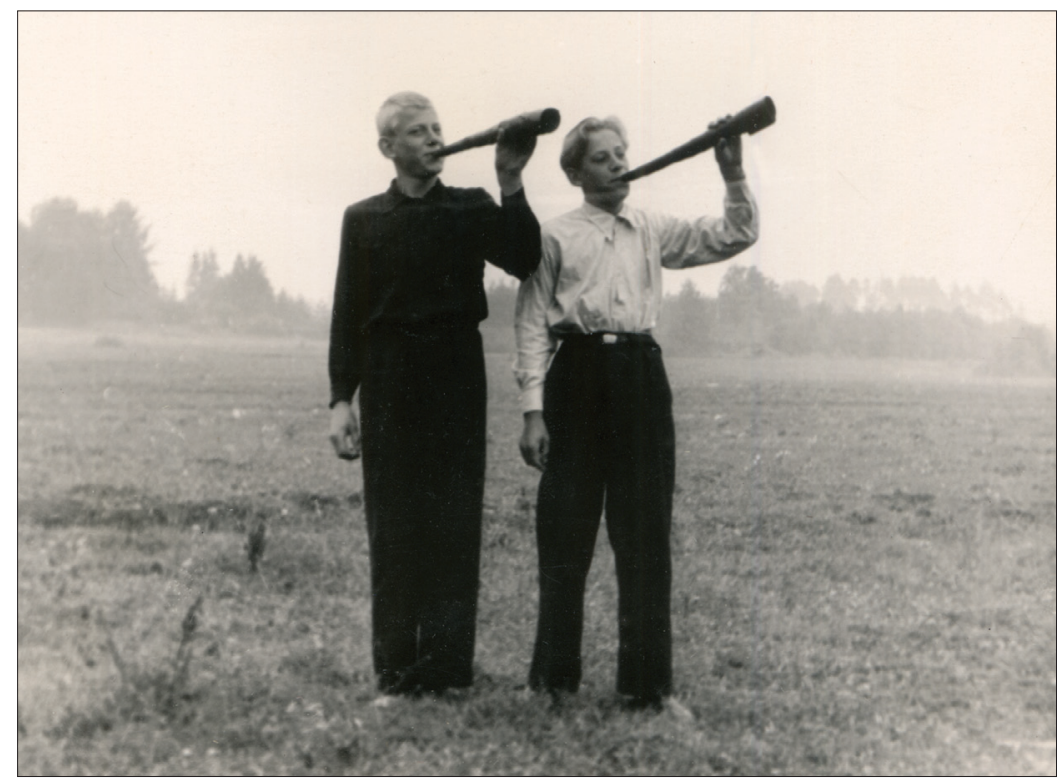

Foto 6. Kaksikvennad Antsovid puhuvad omavalmistatud karjapasunaid. Iisaku khk, Tudulinna k. Richard Viidalepa foto, 1956. KKI 21, 343. 
siin Vainopääl veel kunagi korduvad, või jäävadki viimasteks? (ETMM, 234/ TA 2: ta 3. lk 116).

Õnneks on vana karjapasuna puhumise oskust Haljala mail siiski alles hoidnud pillimehed kohalikust rahvamuusikaansamblist Lahemaa Rahvamuusikud.

Vana tava järgi oli üle kogu Eesti karjapasunate ja muude karjas kasutatud puhkpillide puhumine enne jüripäeva keelatud, sest enneaegne pillimäng võis karjale kurja teha. Kadrina khk Palmse kandis usuti, et üleüldse ei tohi enne jüripäeva metsas hõisata, kõvasti laulda ega kisendada, sest "mets magab" (E 44740 (1903)). Rakveres usuti, et enne jüripäeva ei tohi karjane alletada ega laulda, muidu tuleb hunt talle suvel külaliseks (Eisen 1925: 32). Kadrinas pidanud karjane puhuma esimesel päeval pasunat iga nelja tuule poole, siis seisnud suvel kari hästi koos. Iisakus nõutud koguni, et karjane toogu surnuaialt kolm päeva enne jüripäeva mulda, käigu ümber karja ja puhugu pasunat (Eisen 1925: 21, 14).

Vilepillide käsitluse juures oli mainitud nõidkarjuseid, kes vilega usse ja hunte välja kutsusid. Seda on Virumaal vahel tehtud ka karjapasunaga. 1910. aastal jutustati, et Simuna kihelkonnas Vägeva raudteejaama lähedal Selli külas elanud kunagi karjane Jaan, keda süüdistatud, et too oli kättemaksuks ühe talu karjale murdjad hundid peale saatnud. Peremehe nõudmise peale hakanud karjane Jaan pasunat puhuma ja puhund terve poole päeva ja sellega aand kôik hundid aina rias sealt minema. Sestsaadik polevat Vägeval ühtegi hunti nähtud (EÜS VII 646 (9)).

Eesti pasunalugude viise on vähe üles kirjutatud, kuid Simunast (1908) ja Viru-Jaagupist pärit kaks lugu on trükis siiski avaldatud (vt Tampere 1975: 91). Viru-Jaagupi Roela vallas kuuldud lool, mille viisi pidas meeles A. Pulst 1937. aastal, oli koguni pilliviisi imiteeriv sõnaline tekstki olemas: Taavetile tanguputru, hapupiima kua! (RKM III 5, 213 (1)).

Sikusarv (sokusarv). Teine karjandusega tihedalt seotud trompeti tüüpi puhkpill oli Virumaal siku (soku) õõnsast sarvest tehtud ja sõrmeavadega varustatud sarv. Sarve peenem ots puuriti piki sarve läbi ja kujundati huulikuks. Oma tähenduselt oli sikusarv karjuse käes võrreldav puupasunaga ja sellele laienesid kõik viimasega seotud tavad. Paiguti mäletati sikusarve Virumaal hästi veel 20. sajandi esimestel kümnenditel. Kolm ainulaadset sarveviisi mängiti rahvaluulekogujale viimati 1913. aastal Haljala kihelkonna Aaspere vallas. Iisaku kihelkkonnas Metskülas nähtud loomasarvest tehtud Sirkase härja sarve veel 1924. aasta paiku. Üks naine andnud siis heinalistele sõrmeavadeta sarvega signaali kojutulekuks (autori üleskirjutus väliseestlaselt Mart Kiiverilt Rootsis, 1979).

Kindlalt on Virumaa päritolu kolm Eesti muuseumides leiduvat sikusarve - üks Jõhvist, kaks Kadrinast. Neljas pill võis eeldatavasti pärit olla Väike- 
Maarjast. Ühel Kadrina kihelkonnast pärit sikusarvel (ERM 16 209) on sisse lõigatud aastaarv 1818 ja pillil on neli mänguava. Teisel sarvel (ERM 19 300) on 7 mänguava ja puhumisava sisse on pandud vasktoruke. Kõiki neid ja teisigi Eestis leiduvaid sikusarvesid on analüüsinud ja nende heliread CD-le mänginud Juhan Suits (2004).

Sarv oli karjusele samasugune signaalinstrument nagu pasunadki. Sellega sai külarahvale edasi anda erinevaid viise mängides vägagi vajalikku teavet. Pillilugude selline funktsionaalne kasutus on põhimõtteliselt tuntud karjuste seas mujalgi Euroopas, kuid 1913. aastal Haljala kihelkonnas Aaspere vallas Rõmeda külas K. Viljakule üleskirjutamiseks esitatud lood on ikkagi väga väärtuslike mängijapoolsete selgitustega nn programmilised sarvelood ja Eestis sellistena lausa ainulaadsed. Need mängis kohalik käsitööline ja rahvaluulekoguja Viilip Klaas (50 a). Kolm V. Klaasi sarvelugu (EÜS X 1420/1, 1457 (1913)), avaldatud H. Tampere poolt (1975: 94-95) on järgmise kommentaariga:

\section{Puhuda, kui loomad ilusasti rahulikult söövad.}

2. Puhuda, kui loomad paha peale läinud. Tempo kiirem [kui nr 1], rahutu: loomad on paha peale läinud. Puhuti mõnikord seks, et kodustele märku anda, et nad appi tuleksid loomi paha pealt ära ajada aitama.

3. Puhuda, kui loomad kiili jooksvad. Kiire tempo: loomad jooksevad kiili. Ka mõnikord kodustele signaaliks. Et õnnetus tulla võib.

Siin-seal on Eestis sikusarvede puhul mainitud, et nendega püüti mõnikord isegi tantsumuusikat teha. Samasugune teade on Virumaaltki: aastal 1829 kuulis Christian Hieronymus Justus Schlegel Kloodi kõrtsi juures viiuli kõrval tantsuks mängimas ka sikusarve (Viires 1959: 266). Teadaolevad Virumaa sarvelood (neid on veel üks Kadrinast ja kolm lutusarvelugu Viru-Jaagupist) pole siiski tantsuviisid, vaid iseloomult pigem signaalid. Neid viise on avaldatud ka trükis (Tampere 1975: 95) ning muusikaliselt läbi uuritud (Haasma 1986). Lisaks on avaldatud ka kogujale suuga ette lauldud Lüganuse kolm sarveviisi (Rüütel 1992: 230-231).

\section{Idiofonid}

Idiofonide puhul on helitekitajaks pilli materjal oma jäikuse või elastsuse tõttu, nt lokulaud, parmupill jms.

1. Lokulaud (Virumaal ka kola) kuulub nn löödavate idiofonide hulka. Lokulaud koosnes põikpuu küljes rippuvast puulauast, mille vastu löödi vaheldumisi kahe puuvasara või nuiaga erinevaid rütmilisi signaale. Iga kindel rütm tähendas kindla sisuga teadet, mida ümberkaudne rahvas üheselt mõistma pidi. 
Virumaal löödi vanasti lokku (Erna Ariste lokulauauurimuse järgi - Ariste 1934: 17, joonis 7) eeskätt “tööliste kojutulekuks”, siis "karja kojutulekuks" ja "tulekahju teadaandmiseks". 1930. aasta seisuga sedastas E. Ariste, et "PõhjaEestis on peaaegu ainukeseks ülesandeks tööliste kojukutse” (samas: 18). Kõige rohkem kasutati lokulaudu nähtavasti mõisates, kus see 19. sajandi lõpus juba kaduma hakkas, mõnes kohas asendas seda aga rippuv kell. Üks selline on praegugi Virumaal Sagadi mõisa väravas alles. Mõnes kohas võeti puust loku asemele tarvitusele raudsed lokud - adrahõlm, rööpa tükk jms (Virumaalt on teateid Vaivarast ja Väike-Maarjast).

Lokulöömise iseärasuste ja kõla kohta leidub Eestis teateid vähe ning sellel taustal on üsna huvitav detail Kadrinast, kus kahest löögivasarast "teine vasar on pehmemast, teine kõvemast puust, teine heledama (kõrgema), teine tumedama (madalama) kõla jaoks" (samas: 6).

Virumaalt teada olevad löömisrütmid on erinevalt Lõuna-Eestist olnud E. Ariste uurimuses lk 9 esitatud kaardi järgi suhteliselt lihtsad. Jõhvis, ViruNigulas ja Kadrinas löödi (löökide täpne rütmika pole kahjuks teada) "ühe käega üks, teisega kaks lööki”, Jõhvis veel "ühe käega üks, teisega kolm lööki”, Haljalas "kummagi käega vaheldumisi üks löök”, Viru-Nigulas “ühe käega üks pikk, teisega üks lühikene löök”. Need on vaid juhuslikud teated. Muidugi oli igas ümbruskonnas oma kindla tähendusega rütm, mida kõik kuuljad üheselt mõistsid. Vahel aitasid rütme meeles pidada onomatopoeetilised või värsilised kõlaimitatsioonid, nt Kadrinas: "Kila-kola. Plaga-plaga", Simunas: "Parraparra, mürin" või "Tulge kokku!"

Mõnikord on meile aga endisaegse lokulöömise peen märgiline tähendus raskesti mõistetavgi. Mida arvata näiteks Simunast pärit teate kohta? "Kui löödi kola [st lokku] üks kord, siis pidi tulema toast välja peremees, kui 2 korda, siis kõik täisealised, kui 3 korda, siis ka perenaine" (samas: 14).

Nagu märgitud, olid üheks lokkude kasutuskohaks mõisad, kus loku või kella löömisega teolistele teateid edastati. Sellel taustal on tähelepanuväärne, et ainult Virumaalt Jõhvi kihelkonnast on teada ka vastavat fakti kajastavad regilaulud (Vana kannel VIII: 401-403). Üks näide laulutüübist "Kubjas, lase lõunale!":

Meie kulla kupjakene, armas aida Jaanikene!

Löö keppi, kelista kella, lase lapsed lõunaella, õigel ajal õhtaella!

[---]

(H III 1, 96 (4) < Jõhvi khk, Türsava v (1888).) 
Et sõnade löö keppi puhul on ikka tegemist lokuga, tõestab ka värss teisest lauluvariandist: Lüe lokko ja kelista kella! (Voka v, 1908).

2. Parmupill kuulub mõne muusikariistade klassifikatsiooni järgi idiofonide, teisalt aga ka puhkpillide sekka. Parmupill (Virumaal veel suupill, pöupill, konnapill) oli kogu Virumaal tuntud metallist muusikariist (Tõnurist 1996b: 117, joonis 15). Harva mängiti seda siin 20. sajandilgi, kuid üldiselt hakkas pill kasutuselt taanduma juba 19. sajandil. Parmupillimängija oli Viru-Nigula kihelkonnas Pada vallas sündinud Leonhard Laks (1922-2008), hilisem Sonda kooli kauaaegne õpetaja ja Virumaa tuntud kultuuritegelane. Oma pilli saanud ta Sondas külakooli tööle asudes kohalikult sepalt. 1930. aastate lõpus heliplaadistas Jõhvi kihelkonna Vasavere külast pärit vile- ja parmupillimängijat Ruuben Keslerit (1878-1965) Riigi Ringhääling. Mõlema mehe parmupillimäng on avaldatud noodis ja CD-l (Jaago 2011).

Tavaliselt tehti parmupille vanasti ise või tegid neid külasepad, kuid 20. sajandi algukümnenditel on Esto-Muusika vahendusel neid ka poest ostetud. Endel Metsa kirjapanekus on aastast 1941 olemas Jõhvi kihelkonnas Kohtla külas elanud Toomas Lauri (66 a) jutustus parmupillist:

Paarmupill, see tehti vikati seljarauast või siis mõnest jämedamast traadist. Keel tehti vikatist ehk terasplekist. No raam võeti siis huulte vahele ja ise uriseti lauluviisi ja siis sõrmega tõmmati seda keeleotsa ikka "pirra, pirr, pirra, pirra”. Kui mina poisikene olin, siis oli mõnel veel see pill, no

Foto 7. Pillimees Ruuben Kesler parmupilliga. Jõhvi khk, Vasavere $k$. Foto: Parikas 1938. ETMM foto, ERA fotokogus 851.

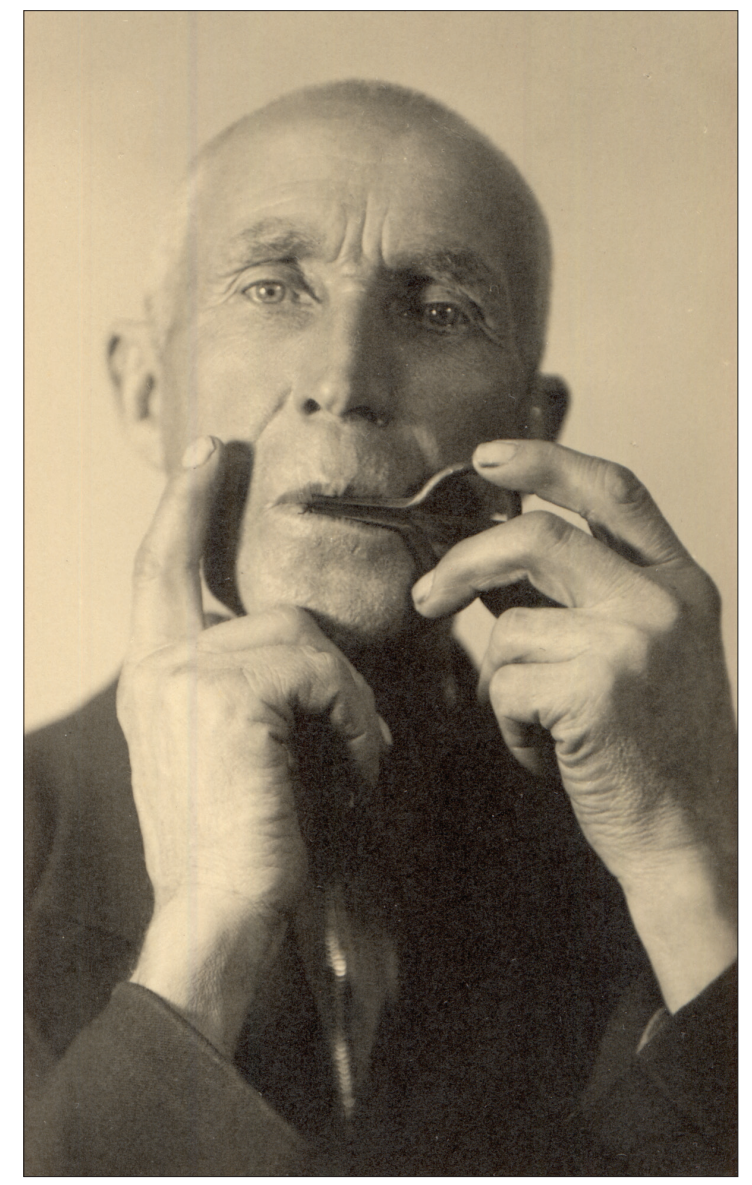


nõnda aastat viiskümmend tagasi. Ennevanasti tantsiti ka selle pilli järele kõrtsis. (ERM KV 56, 239.)

Kammi- või parmupilli on parema tantsupilli puudumisel tantsuks mängitud ka Viru-Jaagupi Küti vallas (ERA II 119, 15 (7), (1934)).

Aino Källo on 1962. aastal kirjeldanud Lüganuse kandi vanu pille, sealhulgas ka pöupilliks kutsutud parmupilli ja pajukoorest pikka piibarit: Pöupill oli üks traat kõvera kieretu, üks õts ku muna, tõine õts lahtine, varras käis läbi, pöupilli vardal konks, sene külgä lei, ois suu ies, õhutas, sis pöu-pöu-pöu mängis (EKI KT 189, 166-167). Pöupilli-sõna juures on tal märge "paupill?”.

Iisaku poluvertsikutelt on 1937. aastal fikseeritud ka parmupilli venepärane nimekuju - vargan, vrd vene варган: Õlgedel mängiti [jõulude aeg] vargani (parmupill) (ERA II 166, 290 (82)).

Kogu Eestis populaarseks on väikekandlemängijate seas osutunud ViruNigula kandi muusikategelase ja rahvaluulekoguja August Krikmanni poolt 1947. aastal noodistatud üks labajalavalsiline "Parmupillilugu" (A. K. noodivihikud: ETMM, M 122 - 1).

Parmupillimuusika kõlab üsna omapäraselt ja selles õiget viisi tabada on kuulajal mõnikord üsna raske, mistõttu laulnudki 1930. aastal 82aastane Juhan Treilmann Tudulinnas (Iisaku khk) Karl Leichteri fonograafile humoorikalt, kuid rõhutatult monotoonselt, sõnu vaid kahel noodil intoneerides: Tuna, tuna, tuna, tuna, tunna-tu, tunna-tu, tunna-tu. See olnud tema "Parmupilli (suupilli) lugu” (ERA III 6, 26 (32), Fon. 306 d).

Tore humoorikas on Kadrinast pärit "Ärjapillilugu", koos viisiga on ka sõnad, kusjuures kolmes värsireas imiteeritakse parmupilli-suupilli (võis ehk olla ka: torupilli?):
Ämm püu, püu, püksid jalga, $k a, k a, k a$, kalits kõrva, ma-ma-ma, mammud sisse,
Kolga mõisa tiule
sitket sitta tõstma,
kõva kesa kündma.
(EÜS VII 242 ( 59), (1910).)

3. Muudest rahvapärastest idiofonidest on Virumaalt vaid üksikteateid ning pole alati selge, kuivõrd laialdaselt mõnda neist ühes või teises piirkonnas tunti ja kasutati.

Luuavars. Mõneski Eesti piirkonnas on rütmi- ja mürapillina ülemeelikus meeleolus kasutatud pikka keppi, millega tõmmati rütmis kraapides mööda põrandat või pinki, millele vajadusel tuhka peale raputati. Selliseks käepäraseks kepiks oli kõige sagedamini luuavars. 
Simuna kandis Kissa külas mängis aastate 1922-1925 paiku külasimmanil orkester, mis koosnes kandlest, viiulist, vahel oli ka luuavars abiks, kusjuures sellega tõmmati, et tolm käis üle pea, parmupill mänginud ka kogu aeg kaasa, vahel löödud labakäega vastu tooli põhja. Viisipillideks olid viiul ja kannel, ühel äälel tõmmati kõik see lugu, luuavars passiks vastu põrandat möuh ja möuh. Kui põrand oli liiga kuiv, visati vett maha, luud toodi otse köögist, vitsad otsas. (Autori üleskirjutus Haljalas 1973 < Leo Kaljuvee, 72 a, pärit Simunast.)

Pangem ülaltoodud jutust tähele, et tantsurütmi mängiti ka toolipõhja pihta käega lüües.

Umba - “Tõmba-Jüri”. Tundub, et üle-eestiliselt külakapellides nüüdisajalgi laialt kasutusel olevad loogakujulised metallkõrinatega varustatud rütmipillid umbad (saksa Bumbass) või jauramid polnud Virumaal vanasti eriti levinud. Mõnevõrra levisid nad Eestis vist alles 20. sajandi algupoolel (Tõnurist 2007: 306-307). Sellel taustal väärib tutvustamist üks naljatlevalt “Tõmba-Jüriks" nimetatud umba põhimõttel rütmi andev löökpill, mida nähti 1930. aastate paiku Vaivara kihelkonnas Puhkova külas. Ilmselt oli pilli konstruktsioon kohalik ühekordne leiutis. See oli tehtud 1,2 m kõrgusest, ülal kaheharulisest sarapuust. Harude külge olid kinnitatud kuljus ning lusikalabast ning viksikarbi kaanest ja põhjast tehtud helistid. Harude vahele oli seotud pingul nöör, mille vastu löödi sirge pulgaga (u 30-40 cm pikk). Pilliharude jala otsas olnud midagi vildist tombu sarnast. Tantsuloo ajal löödi 1. rõhulisel taktiosal "Tõmba-Jüri” jalaga vastu maad, rõhutul 2. osal löödi pulgaga vastu nööri. Tantsuks mänginud viiul, vahel kaks viiulit ja mõnikord isegi klaver. Selle rütmipilliga olevat mängitud isegi Merikülas tuletõrjeseltsis (autori üleskirjutus Rootsis Eesti Metsakodus eakalt Mart Kiiverilt, 1979).

Algeliste umbade hulka kuulus ilmselt ka põiega pill, mida 1973. aastal mäletas Karl Väinsalu (77 a) Altja külas. Ta näinud seda Vergis, kus sellist pilli tegid vahel Soomes käinud mehed - 1-2 korda mängitud ja siis visatud minema. See pill koosnes kepist, selle peal olnud põis, mille üle tõmmati keeleks traat. Tõmmati teistele pillidele kaasa, teinud torts-torts-torts ning krigises ja krägises. Oli randlaste pill ja maa poolt ei tea, et neid kasutatud oleks. Paraku jäi märkimata, kuidas seda torts-torts tehti (autori üleskirjutus 1973. a).

Rahakorjamise kulp. Üht haruldast tavandilist helivahendit, mida küll muusikariistana ei mängitud, on kasutatud Iisakus Kuremäe lähedases Sootaguse külas - see oli kellukesega puukulp, millega pulmas tseremoniaalselt raha korjati.

Alice Moora on seal 1953. aastal üles tähendanud järgmise seletuse:

Teine ommik suuresööma ja lahjade päeva hakkas pruut põrandat pühkima, peen raha visati järjest ôlgedesse, pruut muudkui pühkis ja korjas raha [---]. Isamees pannud esimesena raha kulbi sisse - see olnud 
ämmale. Kulbile seotud kell külge ja kõlistatud siis külaliste ees, kes siis kulbi sisse ämma tarvis raha panid (peigmehe emale). (AI ET 4, lk 76-77, 2016. aastast asub see endise Ajalooinstituudi endise etnograafiasektori käsikirjaline etnograafiliste teadete kogu (ET) Eesti Rahva Muuseumis.)

Nõnda on kellukesega kulbi sisse korjanud ande ka Kihnu kadrisandid ning Saaremaalgi on Mustjalas pärast tanutamist pruudile kinga sisse raha korjatud kepi otsa seotud kellukesega (pikemalt niisugusest rahakorjamise viisist ja selle eeskujust vt Tõnurist 2007: 295-296).

Noorpaari voodikell. Lüganuselt Purtse-Liiva külast on pärit huvitav kirjeldus tavast, millel võis olla ka sigivusmaagiline tagapõhi:

Õhtul jälle, kui pruut peigmehega magama läinud, siis sidund isamees ehk mõni teine nende voodi külge kuhugi kella, kas lamba tillukese või suure lehmakella. Seda tõmmatud siis kustki kaugemalt nöörist ja isamees laulnud:

Ai, till, till, till!

Minu pruudil kell

ja ise tema voodis teki all

(ERA II 287, 67 (10), (1940).)

Mardiisa kelluke. Jõhvi mail on kirjeldatud, et mardiisal oli aisakell käes ja kaelakott kaasas [---] Esmalt kõlistab isa akna taga ja palub sisselaskmist (RKM II 106, 645/6 (7)). Tegemist on mardisantide rituaalse kellahelistamisega, mis Eestis mujalgi tuntud oli (Tõnurist 2007: 297-298).

Traditsioonilised helilised märgid. Eestis on nii mõneski maakohas mingil erilisel tseremoniaalsel viisil märku antud pulma lõpetamisest. Selliste märkide juurde kuulus rituaalne kolistamine või kraapimine. Iisaku kihelkonnas Taga-Varesmetsa külas on vanainimesed 1953. aastal Alice Moorale rääkinud:

Viimasena antud pulmas sü̈̈a "isamehe putru”, siis oli teada, et pulm lõpul ja külalised sõitku koju. Teiseks märguandeks oli veel see, et pulma pererahvast läks keegi õue ja kraapis millegagi kõvasti väljaspoolt seina nii, et see sisse pulmalistele oli hästi kuulda. Siis teati, et pulma lõpp. (AI, ET 2, lk 267.)

Nõnda on tehtud mõnel pool mujalgi. Lüganusel Purtse-Liiva külas rääkinud üks Järva-Jaani päritolu mees, et pulmade lõpu märgiks olnud kapsasupp ehk hernesupp, mõnel pool taotud ka kiviga vastu seinu (ERA II 287, 69 (10), (1940)).

Omamoodi ainulaadne on aga Kadrina-Ilumäelt Palmse kandist pärit tava, millest rahvaluulekoguja Johannes Sõsterile rääkis ema, 1842. aastal sündinud Madli Sõster. Seal oli nimelt puunoti tagumisega teatatud kogukonnale heinatöö lõpetamisest. 
Kõige rohkem lauleti heina lõpetusel. Siis kilkas suur ja veikene. Kui heinalau uks "kinni tauti", siis tehti niisugust kära, mis kõikidele küla heinamaadele pidi kuuluma. Lau ukse kinnitagumine oli nii, et kes viimse lau ukse ette noti pani, sellesama notiga vähemalt kolm korda kõigest jõust vasta lauseina palkisid virutas, nii et mets kajas. Siis pandi viimne uksenott ette. Lukku ei panda veel tänapäevgi heinalau uksi. Kära järele teati, kes pere oma heinategemise lõpetanud. (EÜS VII 220 (1910).)

Idiofonide hulka kuuluvad veel kolmnurksed trianglid, mida Virumaal teiste pillide saateks löödi, ning mitmesugused signaalse, vanasti kindlalt ka maagilise tähendusega puust ja plekist lehmakrapid, hobuste metallist kaelakellad ja aisakellad ning kuljused.

\section{Membranofonid}

Helitekitajaks on pinguldatud membraanid, mis on tehtud nahast, kilest jms materjalist. Virumaal kasutatud membranofonidest on teateid trummi, kammipilli ja põsepilli kohta.

Kammipilli on siin-seal kasutatud, eriti külanoorte poolt, kui mõnda teist sobivat muusikariista ei juhtunud tantsuks mängima. Viru-Jaagupis Küti vallas Kui pillimehi ei leidunud, siis lauldi tantsu jaoks ehk mängiti kammipilli või parmupilli. (ERA II 119, 15 (7), (1934).)

Ka Haljala kihelkonnas Altjas mängitud kui muud ei olnud, siis kammipilli.

Trumm. Trummide kasutamise ja trummitüüpide kohta on konkreetseid teateid väga vähe. Vanadel pulmapiltidel võib siiski näha väiksemaid, enamasti ühepoolseid, kõrinatega varustatud ja tamburiini meenutavaid raamtrumme, mida ühe pulgaga löödi ja nõnda lõõtspillimängule rütmisaadet tehti.

Viru-Nigula kihelkonna Vasta külas olnud 1920. aastail ühes musikaalses peres teiste pillide seas ka väike trumm, kahe poolega, pisike nagu sõel, löödi käega.

Põsepill. Kuigi selle pilli moodustab inimese keha, täpsemalt põsed, võib tinglikult ka niisugust helitekitamismoodust muusikariistana käsitada.

Jõhvi kihelkonna Vasavere külas elanud rahvapillimehe Ruuben Kesleri (1878-1965) mängitud nn põsepill jääb lausa kogu Eesti taustal ainulaadseks nähtuseks, sest muid ülestähendusi sellest pillist mujalt pole. Põsepilli mängu heliplaadistati 1930. aastail Riigi Ringhäälingus. Põsepilli resonaatoriks on mängija enda pinguldatud põskedega suukoobas. Heli tekitamiseks pidi vastu oma põski sõrmeotsi nipsutama, kuid pikapeale jäänud põsed kibedaks. R. Kesler oli põsepillimängu õppinud karjapoisipõlves vanematelt meestelt (vt ka Pulst: 817-819). 


\section{Keelpillid}

Kannel. Põhiliseks vanaks keelpilliks oli Virumaal, nagu mujalgi Eestis, ilmselt kannel. Algul oli see tehtud seest õõnestatud puutükist, kuid 19. sajandi jooksul asendus muistne väheste keeltega (kuus ja veidi enam) väikekannel uuetüübilise psaltritest ja tsitritest mõjustusi saanud uue kandlega, mille suur, trapetsikujuline kõlakast tehti tavaliselt kokkuliimitud lauakestest ning keelte arv ulatus vähemalt paarikümneni. Uus kannel kandis Põhja-Eestis, sealhulgas Virumaal, koguni võoorapärast nimetustki - simbel, simmel (tsimmel):

Simmel, hiljem oli see Wanemuise kannel, simlimängu tehti ikke. Iljem olid kandled, topeltkeeltega, klaffid peal, ilusad pillid. [---] Simmel oli kõige lihtsam simmani pill, ise tehti. (autori üleskirjutus 1973. a Haljalas Leo Kaljuveelt, pärit Simunast.)

Tõenäoliselt rahvuslikkust rõhutada püüdes hakati mingil ajal 20. sajandi esimesel poolel Eestis simbli-simli võõrapärast nimetust kirjakeeles vältima ja valitsevaks sai Põhja-Eestiski vana termin, kuid algselt hoopis teistsugust pillitüüpi tähendanud kannel.

Vanapärase ehitusega, seest ühest puutükist õonestatud kannelt pole Virumaalt muuseumidesse jõudnud. Mälestus sellise muinaskandle imepärasest tegemisest säilis aga regivärsilises rahvalaulus "Kannel”, millest Virumaalt on üles kirjutatud üheksa varianti (Eesti rahvalaulud I: levikukaart lk XXXVII ja tekstid lk 1-5). Ülo Tedre ja Veljo Tormise koostatud "Regilauliku" (1973: 21-22) kaudu sai just Lüganuse kihelkonnas ülestähendatud regilaul üle kogu Eesti väikekandlemängijate seas enim lauldavaks lauluks kandle tegemisest kolme eri kalaliigi luudest. See tekst on ka ainuke, milles mainitakse vana eesti kandle keelte väiksemat arvu: ei saand kannel kaikumaie, kuuekeelene kumama. Mis kandle nimetusse puutub, siis kõigis Virumaa üheksas regilauluvariandis on see kindlalt kannel (eri käänetes: kandle, kandela, kandeli, kandelile, kandelale, kannelile).

Ühest puust õonestatud kõlakastiga pilli kohta oli aga säilinud mälestus pärast viimast maailmasõda USAsse emigreerunud kanneldaja Walter Raudkivi-Steini perekonnatraditsioonis. Tema tütrest Lilian Esopist on hiljem saanud USA Baltimore'is suur eesti kandlemängu edendaja.

W. Raudkivi-Stein (1902-1980) sündis Virumaal Haljalas asunud veskikohas ja elas ning kanneldas hiljem Viru-Jaagupis. Haljalas kodumaja seintel olevat rippunud ühest puust õõnestatud kõlakastiga kannel ja sellel olnud peal 12 keelt. Selle kandlega seoses räägiti peres lugu, et seda pilli on aastakümneid varem, 19. sajandil, mängitud möldri tütre pulmas. Mängija oli leitud hiljem kõrtsis surnuna ja arvati, et selle kandle jättis just tema Raudkivide perele 


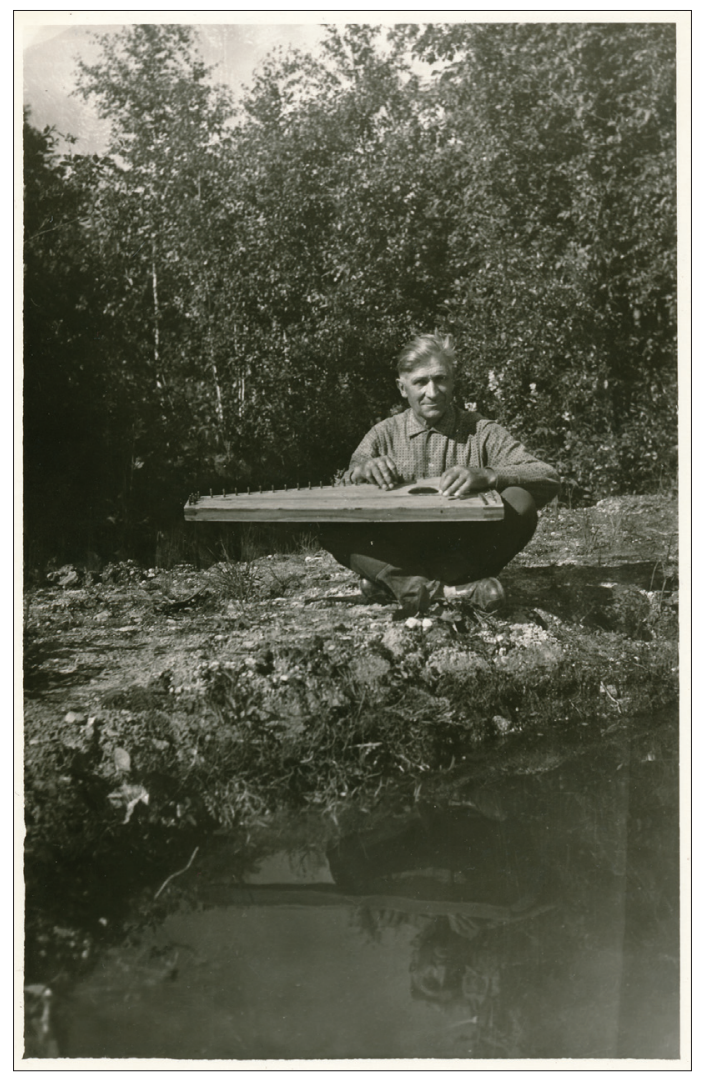

Foto 8. Kandlemees Rudolf Maamets. Rakvere raj, Viitna k/n, Hõbeda $k$. Herbert Tampere foto, 1969. ERA, Foto 8828.

kuulunud veskisse. Lastel pole lubatud seda pilli isegi puutuda. Kui Walteri vanem tütar soovis kannelt mängima õppida, muretses isa talle kandle, millel oli 28 pillikeelt ja mis meenutas uuemaid tsitri-tüüpi kandleid (andmed pärinevad Carl Rahkoneni ettekandest “The Estonian Kannel in Baltimore” teisel rahvusvahelisel kandleajaloo teaduslikul konverentsil Vilniuses 16. novembril 1994, käsikirja koopia on artikli autori valduses). Hiljem on W. Raudkivi kujunemist kandlemängijaks ja -meistriks eesti keeles lähemalt käsitlenud USAs elav rahvapilliuurija Ain Haas oma 2016. aastal ilmunud artiklis "Rahvapillipärandi säilitamine Eestis ja välismaal” (Haas 2016: 104-106).

20. sajandi algupoolel kogutud mälestused kandlemängust tõendavad, et uuemat tüüpi kandled ehk siis juba tegelikult simlid kinnistusid Virumaa rahva-traditsioonis peamiselt 19. sajandi viimase veerandi jooksul. Kõige suurem Virumaa simlite kollektsioon on Eesti Rahva Muuseumis (Viru-Nigula, 
Lüganuse, Jõhvi, Viru-Jaagupi, Iisaku). Nähtavasti kõige varasema dateeringuga (“1897”) 17keeleline raudpulkadega Virumaa kannel (Mart Torpani pill) asub aga hoopis Peterburis Peeter Suure nimelises Antropoloogia ja Etnograafia muuseumis (Kunstkamera) ja pärineb Vaivara mõisast Repniku külast.

Uuemat tüüpi simlid olid mõnikord üsna väikese, lauakestest kõlakastiga ja ka väheste keeltega. Nii on Viru-Jaagupist pärit kandle pikim külg vaid $34,5 \mathrm{~cm}$ pikk ja lühim $20,5 \mathrm{~cm}$, pilli laius on $17 \mathrm{~cm}$, kõrgus $6 \mathrm{~cm}$ ning peal on vaid 11 keelt. Selle pilli nurgeline kõlakast on kokku löödud lauakestest (ERM A 604:258). Väike on ka Lüganuse külast pärit 1906. aastal tehtud samasuguse kujuga kannel (pikim külg 57,5 cm, lühim 24,3 cm, laius $25 \mathrm{~cm}$ ), millel on 17 keelt.

Lauakestest kokku liimitud kõlakast ongi uuema kandletüübi tähtis tunnus. Sellise kõlakasti kokkuliimimine nõudis suuremat puutööoskust ning harva on uuemate pillide kõlakasti tehtud lihtsamalt, õonestades seest sobiva kujuga laia lauajuppi, millele kõlakaas peale pandi. Just nii on tehtud omamoodi haruldane, õoneskorpusega, pealmise kõlakaanega ja 21 keelega kannel ViruNigulast (ERM A 499:7). Vaatamata arhailisele tegemismoodusele on see pill moodsa kaarjajoonelise viltuse pikiküljega, kusjuures üks kahest kõlaaugust on südamekujuline (see vastas ka tolle ajastu vaimule, mil lauludes valitses armastus ja sentimentaalsus). Niisuguse õõnestatud korpusega uuemaid kandleid on tehtud muide ka Võrumaal.

Varasem mängutehnika oli uuematel kanneldel nn katmistehnikas mängimine, mille juures vasaku käe sõrmed katavad teatud keeli ning paremas käes oleva tikuga tõmmatakse üle vabade keelte (rahvapäraselt tikuga mäng), saades niimoodi ka vajalikke akorde. Sellist siblivat mängumoodust nimetati mõne teate järgi kraapimiseks. Kraapimisega mängu puhul olnud kannel tavaliselt süles põlvedel või laual lühemate keeltega mängija poole. Selle tehnika puhul ei kasutatud saatebassegi (ilma bassikeelteta mängitakse lü̈̈es - Rakvere). Ühe tüüpilise arhailises tehnikas akordilise kandleloo mängis 1951. aastal siblides Aino Korts (37 a) tolleaegse Väike-Maarja rajooni Käru külanõukogus (Simuna khk), nagu Eesti Teatri- ja Muusikamuuseumi viisikartoteegis B. Kõrveri noodistuse juures märgitud on.

Tihtilugu olnud simlil ka kolm bassikeelt. Juba 19. sajandi lõpus hakkas levima näppetehnikas mängimine ehk nn harfipärane mängutehnika, mille juures parem käsi mängis üldjuhul viisi ja vasakuga tõmmati saateks bassikeeli kaasa. Mängimine toimus ikka lühemate keelte poolt nagu tikumängu puhulgi.

Juhtus ka nii, et kraapimiselt, tikuga mängimiselt uuele tehnikale üle läinud simlimängijad mängisid viisi harjumuspäraselt ikka vasaku käega. Tihtilugu pöörati aga uue tehnika puhul pill siiski teistpidi - pikemate keeltega, sh bassidega, mängija poole. Nii on juhtunud tavaliselt nooti tundvate mängi- 
jatega, kellele saatepartii nootide nägemine oli vasaku käe partiina loogilisem (vrd klaverimäng), nagu on mõned vene ja soome kandleuurijad väitnud juba 20. sajandi alguses.

Isevärki kannelt mäletas 1973. aastal Haljala khk Altjas pillimees Karl Väinsalu (77 a, ta jutustas ka katmistehnikas tikuga mängitavast simlist), kes näinud 8-9aastase poisina Sagadi mõisas kandletaolist keelpilli, mis olnud nagu laud, neljakandiline, kaas peal. Keeled olid topeltkeeled. Kui lugu olnud minooris, siis keeranud mängija paar keelt teise tooni peale. Pill olnud nii suur, et väljas sellega ei käidud. Mänginud seda keegi eestlane (autori üleskirjutus Karl Väinsalult Altjas, 1973). Üks selline "laud-kannel” on toodud ERMi Lüganuselt, kusjuures see lõpuni viimistlemata ja pillina kasutamata jäänud kannel avastati alles siis, kui köögilauda lammutama hakati ja lauaplaat lahti tõsteti. Niisugused suured lauakujulised kandled on Eestis mujalgi kasutusel olnud (Tõnurist 1996c: 25).

Paralleelselt uuema kandle (simli) leviku ja kinnistumisega rahva seas hakkasid mõnevõrra levima ostupillid - mitmesugused nn tsitrid, enamasti välismaa vabrikutes või pillitöökodades toodetud. Neid sai 19. ja 20. sajandi vahetusel osta ka tellimisel. Eestis oli tuntud pillimüüja Avelinius Tõnissoni pilliäri Türis, kust sai osta hulga erinevat tüüpi tsitreid, sh nn tuleviku kandleid, Wanemuise kandleid, ning lõõtspille ja teisigi pille (Tõnurist 1996a, foto lk 53).

Mõnel edasiarendatud tsitritüübil olid peal klahvid, mille abil sai akorde mängida, esines ka eraldi pillikooridesse seatud saateakorde (sh minooris akordid, mida rahvapärastel kanneldel-simlitel polnud). Selliseid uuendatud "kandleid" sattus Virumaalegi, nagu näiteks kleebisega "Kronen-Zither-Reform" tuleviku kannel Iisaku khk Oonurme külas (ERM A 600:67). Samasuguste uuenduslike tsitrite hulka kuulub Virumaa Muuseumis hoiul olev "Reicher Pianokochordia", mille kinkija abikaasa oli lasknud tuua 20. sajandi alguses Saksamaalt. Mängija elanud tol ajal Kundas ja käinud selle pilliga pidudel mängimas kuni 1943. aastani (VM 1242).

Uuemaid kandleid-simleid mängiti tihtilugu tantsuks, kuigi nende kõlajõud polnud kuigi suur. Kuidas pillihäält tugevdati? Meeleoluka jutustuse endisaegsest pillimängust Jõhvi khk Kohtla külas pani kirja Endel Mets 1956. aastal:

Pillimees õli Sompas. Ja sä̈̈lt siis käidi kutsumas nagu linatalgule ja pulmide. Kas tuli siis ise, vai tuadi obusega. Tasu ei maksetud, aga viina nindapidi kui jõudasid juua. Kõige rohkemb õli ikka kannel, nagu talgul. Sie pandi tõrre põhja päälä, siis iast kõmas. No õli ärmuanikas kaa, mõlemid mängis, aga kannel ikke õli rohkemb. (ES KT 147, 13.)

Ka Aino Källo kinnitas 1961. aastal Lüganuse olude kohta, et ku kannelt mängiti, sie ôligi enne tantsupill, torupilli järälä tantsiti (ES KT 189, 166). 
Just tutvustatud uuema kandle ajalugu silmas pidades, saab mõistetavaks 66aastase jutustaja kinnitus kannelde ja lõõtspillide üheaegsest mooditulekust Jõhvi kihelkonna Kohtla küla ümbruses (jutu pani kirja Endel Mets 1944. aastal):

Ennemast jua suured kiikked ehitedi [---], sis kui imu sai õtsa, siis männiti rinngi ja lauleti pera, siis tulivad kannled ja ärmanikad, siis tanttsiti kaa. Mõnel õli paarmupill tasskus, sene järälä mõnikõrd tanttsiti kaa, ninndat midagi ei ôld... (ES KT 80, 7.)

Iisaku kihelkonna Varesmetsa külas jutustas 81aastane naine 1955. aastal:

Kiige juures lauldi palju. Poisid laulsid pilli järgi, meie laulsime pillita. Poisid laulsid kandle järele ja vene pilli - lõõtsa järele. Suuremp jägu oli ikke kannel, kandle järele sai tantsida. Laulsime hulgakesi koos. Poisid käisid küll. Kannel oli kaelas, aga laulsid vähe. (KKI 20, 332 (8), see praeguse Eesti Keele Instituudi käsikirjaline folkloorikogu asub nüüd Eesti Rahvaluule Arhiivis.)

Vene kannel-gusli Alutagusel? Huvitavaid fakte eesti ja vene kandletraditsiooni ristumisest Iisaku poluvertsikute juures võib leida 1955. aasta üleskirjutustes Iisaku kandist. Kuna selle situatsiooni detailide mõistmiseks on tarvis teada üldjoontes eesti kandle ajalugu, on selle probleemi tutvustamine paigutatud Virumaa kannelde käsitluse lõppu. Seda situatsiooni kirjeldan oma ühe varasema uurimuse põhjal (Tõnurist 1985: 103-104).

1955. aastal elas Vaikla külas kandlemees Taavet Murumäe (varem venepäraselt Štšelkin), kelle mängu juba 1930. aastal fonografeeris Karl Leichter. Niisiis, 1955. aastal seletas T. Murumäe kogujatele, et kannelt siin ei olnud, aga tuli siia külasse (umbes 70 aastat tagasi) Koldsem, vankrirattameister. Tema tegi puupulkadega ja vaskkeeltega. Aga pärast tehti raudpulkadega ja teraskeeltega. Gusli kutsuti enne, pärast nimetati kannel (KKI 20, 577). Aasta hiljem seletas Lemmaku külas 84aastane Eduard Mölder, et vanasti õli ikke kannel sie mänguriist, õigati ka kusli. Sie on kandletaoline, aga keeli õli vähem. Sie pill on Nõmmel, Tudulinnas Härjakarjatse talus piab pill alles õlema... [---] Viiulit õli väga vähe, ikke kannel ja kusli (KKI 21, 357/8 (8; 10)).

Kannel ja gusli on põhimõtteliselt sama liiki pillid, kuid gusli oli puupulkadega ja vaskkeeltega ning vanem, arhailisema ehitusega, kannel aga raudpulkadega ja teraskeeltega, seega uuem pillikuju. Iisaku poluvertsikute külades kohtusid niisiis kaks traditsiooni, ühe pilliliigi kaks stadiaalselt erinevat erikuju - vanem arhailine vene gusli ja uuem eesti kannel-simmel (arhailisele guslile vastav arhailine kannel kadus eestlastel varem). Taavet Murumäelt fonografeeritud kandlelood olid Iisaku etnilistele oludele iseloomulikud: üks 
ilmselt venepärane tantsulugu - pljaska (kasatšokk), teine meenutab aga eesti "Viru mageda" viise (ERA III 6, 39 (52) ja 39 (53)). Küllap oli kogujagi K. Leichter pilli "rahvuse" määramisel kimbatuses, kui ta noodivihikus märkis Гусли. Каnnel (simmel) (samas). Lisame veel, et vanapärased nn labaga guslid olid Peipsi järve idakaldal Oudovamaa venelastel kasutusel kuni 20. sajandi keskpaigani. Eesti asunike vahendusel levisid aga sealsete venelaste keskel ka eesti uuemad kandled-simlid, mida venelased nimetasid ikka gusliks.

Viiul. Tõenäoliselt 19. sajandi jooksul levis üle kogu Virumaa uus keelpill viiul. Tasapisi asendas see tantsumuusikapillina vana torupilli. Üleminekuajal mängitud neid vahel kokkugi, nagu torupilli käsitluses juba mainitud sai (teade Simunast). Mõned torupillilood elasid aga veel kaua aega edasi kohalike viiuldajate (EÜS X 2543 (2) ja 2507 (2)) ning lõõtspillimängijate repertuaaris.

Viiulimehi oli külapillimeeste seas, kuid pilli tarvitati ka koolimuusikas ja maal tegutsenud muusikaseltside orkestrites. 1915. aasta paiku tegutses oma viiulikoor näiteks Haljala kihelkonnas Liiguste koolis. Kuni Esimese maailmasõjani tegutses viiulikoor Rakvere kihelkonnas Sõmeru vallas Raudvere külas, kusjuures selles mängitud ka vanu labajalavaltse ning polkasid. 1930. aastail tegutsenud Viru-Jaagupi kihelkonnas Kulina asunduses ansambel, kus kokku mänginud kaks viiulit, neli kitarri, kannel ja kaks akordsitterit (Pulst: 870 ja 879). Samas kihelkonnas Küti vallamajas peol mänginud tantsuks 20. sajandi esimesel kümnendil ansambel viiulist, kandlest ja mandoliinist (samas: IV).

Üksikteateid on vaimuliku muusika esitamisest. Jõhvi kihelkonna Kohtla külas mänginud Käärdi Juri kodus jumalasõnalaulusid. Mängis viijuli ja naine laulas (ES KT 147, lk 14).

Viiuli kohta kirjutas Viru-Nigula kihelkonnas tegutsenud kauaaegne rahvaluulekoguja ja seltsitegelane August Krikmann 1946. aastal, et

...vanema aja mehed "sügasivad" oma tehtud viiuleid. Valged, värvimata "puukarva” viiulid, nn "võigud” (alias - voigud) rippusid talu tagakambris naela otsas seina peal. Kamfoliks kasutati vahest toorest kuusevaiku. "Lambakints" oli meile kihelkonnas armsamaid kaaslasi talu peredes. Isegi tütarlapsed mängisid. (ETMM, M 122-1, sü 6, lk 2.)

A. Krikmanni poolt Viru-Nigula ja Rakvere mail 19. sajandi lõpuveerandil ja 20. sajandi algupoolel üleskirjutatud viiuli- ja ka paljude teiste rahvapillide lugusid on rohkesti tallel ERAs ja ETMMis. Paraku nõuavad need materjalid tõsist allikakriitilist analüüsi, kuna tihtilugu segunevad neis autentsed üleskirjutused ja koguja enda rahvapärases stiilis muusikaline omalooming.

Igas maakohas leidus kohalikke külameestest viiuldajaid, keda ümbruskonnas tunti ja austati, kuid paraku pole nad Virumaal folkloorikogujate vaatevälja jäänud ja trükiste jm väljaannete kaudu nii tuntuks saanud kui Pärnumaa või 


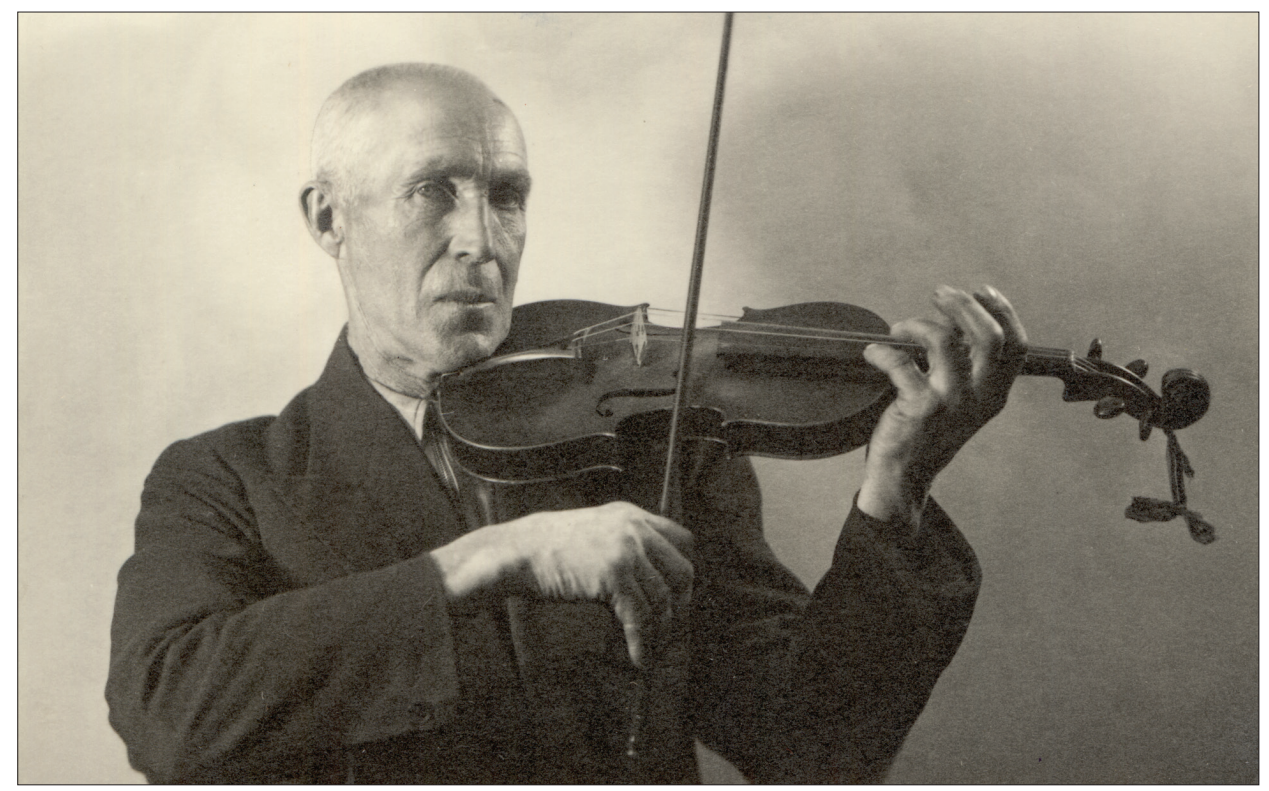

Foto 9. Pillimees Ruuben Kesler mängib viiulit. Jõhvi khk, Vasavere $k$. Foto: Parikas 1938. ETMM foto, ERA fotokogus 852.

mõne teise piirkonna viiuldajad. Viiulit on mänginud, isegi üheaegselt koos suupilliga, korduvalt mainitud Ruuben Kesler Jõhvi kihelkonna Vasavere külast. Kuna tema esituses heliplaadistati just vile- ja põsepillimängu, siis ongi ta kuulsaks saanud nimelt nende pillidega. Toredaid labajalavaltse on kogujatele mänginud 1913. aastal viiuldaja Grooman (eesnimi teadmata, 75-80 a) Kadrina kihelkonna Imastu külas (avaldatud lugusid vt Tampere 1975: 152-153). Oma "Arju torupilli" nimelise tantsuviisi õppinud ta otse ühelt Väike-Maarja torupillimehelt.

Mollpill. Virumaalt on andmeid mollpilli (ka mollipill) kohta pea igast kihelkonnast. Mollpill on 1829. aastal loodud rootsi päritolu muusikariistpsalmodikon, mida soovitati luterliku kirikulaulu õpetamiseks ja toetamiseks orelita palvemajades ja koolimajades.

Mollpill on pika kitsa kõlakastiga muusikariist, mis väliselt meenutab küna - moldi, sellest ka nimetus moll(i)pill. Pillil on peal tavaliselt üks soolest pillikeel (harva ka 2-3 keelt), selle all asub pügalatega näppelaud, pilli mängitakse poognaga. Rangelt võttes pole mollpill kuigi vana eesti muusikariist, kuid kuna ta oli väga tihedalt seotud eeskätt talupoegliku koduse vaimuliku musitseerimisega ja pillegi tehti ise, siis on Eestis seda pilli traditsiooniliselt vaadeldud koos rahvapillidega (Tõnurist 1996a: 127, 135). Mõnikord on moll- 
pilli rahva seas kutsutud laulukandleks (nt Kadrinas) või ka harmoonikaks. Simunas Rakke koolis nimetanud õpetaja (aastad 1861-1881) Jüri Brehn laulu õpetamisel kasutatavat pilli harmoneeriks, õpilased aga mollpilliks (Rannap 1972: 86).

Mollpilli aktiivsema kasutamise aeg jääb enamasti 19. sajandi teise poolde, üksikjuhtudel mängiti seda hiljemgi. Veel vahetult enne Esimest maailmasõda mänginud just mollpillil laupäevaõhtuti sirelite keskel oma pikkalised jumalasõna laulud Haljalas Esku kiriku kellamees, kes osanud ka viiulit ja harmooniumi mängida ning tundnud nooti (autori üleskirjutus Karl Väinsalult (77 a) Altja külas 1973). Ilmselt just see mollpill, mis kannab aastaarvu 1867, on juhtumisi säilinud ning hoiul Virumaa Muuseumi kogudes ja sellel on pilli otstarbele sobiv kirigi peal: "Laulage kauniste mängides, Issandale ommas süddames."

Laupäeviti mänginud kodus oma mollpilli ja laulnud ise koraale kaasa Peterburi kubermangus Ljolino eesti asunduses käesoleva ülevaate autori vanavanaisa Kristjan Malt, kes oli sinna välja rännanud 1883. aastal Vaivara mailt.

Mollpillil koraalide mängimist on harrastanud ka Vaivara Peeterristi vanas kabelis koos käinud vennastekoguduse üksikud liikmed, kuid pole teada, kas seda just kabelis palvetunnis tehti või mängiti ainult kodus (jutustaja mollpillimängijast isa olnud pärit Soldinost, vt http://www.folklore.ee/radar/ story.php?area=Vaivara\&id=329).

Muudest keelpillidest võeti 19. sajandi lõpupoolel ja/või 20. sajandi algupoolel kasutusele kitarrid (kitarre) ja mandoliinid (sh mandoolad).

Pärast Esimest maailmasõda mänginud Altja külas, samuti Võsul ja Vergis, kahest viiulist, kitarrest ja mandoolast koosnenud ansambel (autori üleskirjutus 1973. a Altja külas). Palju keerulisema koosseisuga oli nt Simunas Haridusseltsi Muusikaringi tantsuorkestri koosseis: kaks kitarri, kaks viiulit, mandoliin, kaks truba, tšello, kontrabass, ksülofon ja trumm.

\section{Lõõtspill}

Lõõtspilli (lõõtspill, loets, kortspill, harmoonika, ärmuanikas, karmoška jms) levik algas Virumaal, nagu mujalgi Eestis, 19. sajandi teisel poolel, eriti aga 1880.-1890. aastail. See uus moepill leidis talurahva seas kiiresti suure poolehoiu, kuna sobis oma valju ja mahlaka kõlaga eriti hästi tantsupilliks, mis kostis hästi üle peomelu. Lõõtspill sai peagi tõelise rahvapilli tähenduse.

Tavaliselt kasutati ostupille, enamasti Lääne-Euroopast, kuid liikus ka Venemaalt pärit karmoškasid. Kodust lõõtspillitegemist, erinevalt muudest pillidest, harrastati külas palju vähem ja juhuslikumalt, sest uue keerulise 


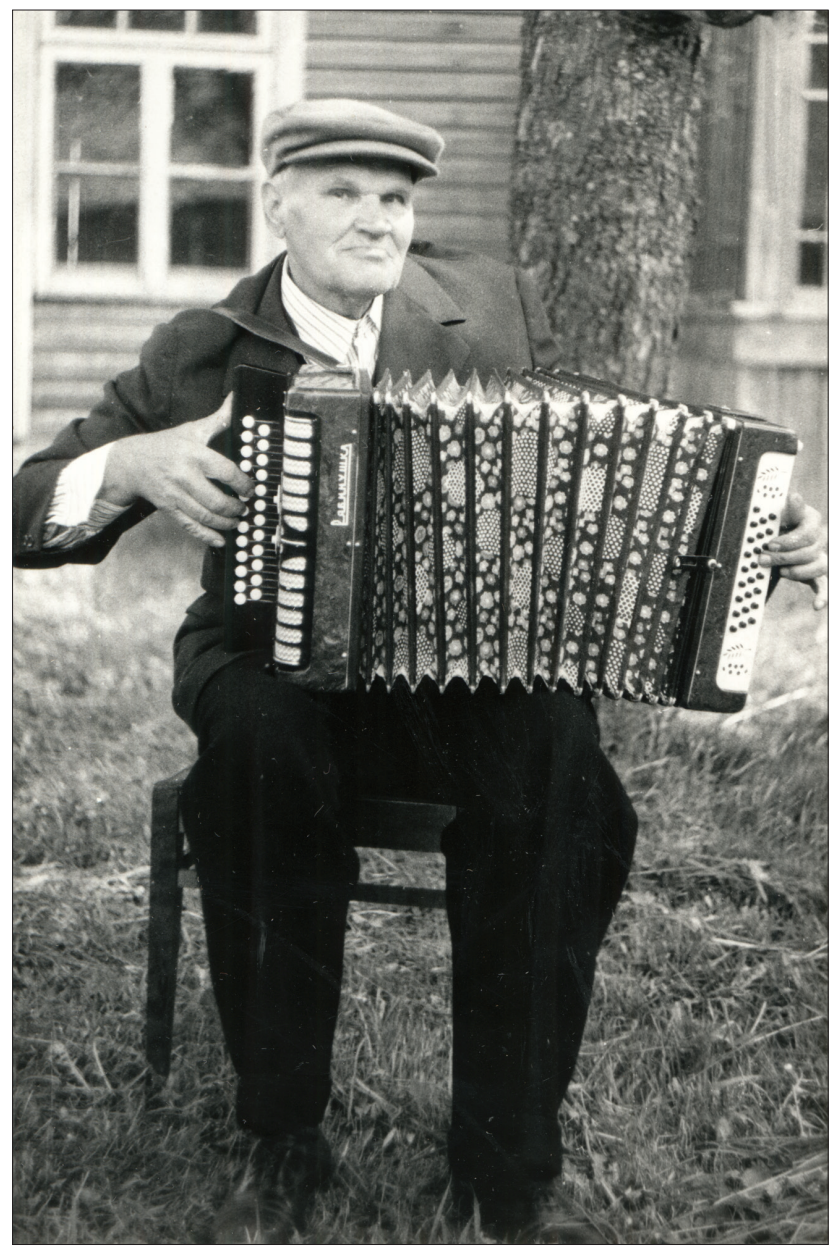

Foto 10. Heinrich Kasemets „vene garmoškaga”. Simuna khk, Raja k. Mart Jallai foto, 1978. ERA, Foto 12272.

ehitusega lõõtspilli tegemine nõudis mitmeid eri oskusi, mida lõõtspilli moodituleku algaegadel tuli alles omandama hakata. Tavaliselt osteti kahe- ja kolmerealisi lõõtspille. Mõnel pillil olnud ka kaks kellukest juures. Võib siiski eeldada, et vanasti tunti mõnel määral ka lihtsamaid ja algelisemaid üherealisi lõõtspille. Näib, et Virumaal kasutati ja kasutatakse tänini kõiki kättesaadavaid lõôtspillitüüpe ja mingist erilisest, ainult Virumaale omasest lõôtspillist, nagu võrokeste Teppo-pilli puhul, ei saa rääkida. Väärib märkimist, et teenekas virulasest lõõtspillimängija Taavi Teinbas pole juhtinud oma lõõtspilliraamatus mingit tähelepanu Virumaa eripärale (Teinbas 1994). Ilmselt väljendus lõõtspilli eripära Virumaal siis pigem repertuaari tasandil. 
Esimese maailmasõja aegu võis hea lõõtspill maksta 15 rubla või enamgi. Igas ümbruskonnas kujunesid ajapikku oma tunnustatud lõõtspillimängijad, kes mängisid mitmesugustel külaüritustel, eriti aga pulmades, talgutel ja simmanitel. Kujunes välja omaloomingulise muusika tegemine ja ka meeste laulmine lõõtspilli saatel. On teateid, et lõõtspilli mängitud tavaliselt üksinda, kuid mõnikord kasutati seda väikestes külaansamblites koos viiuli ja kandlesimliga, vahel lisati veel triangel. Omamoodi hea näide sellest, kuidas hinnati lõõtspilli, mis seostus külaintelligentsi silmis ennekõike külameeste bravuuritseva lõbutsemisega simmanil-särul, ning peenemaks peetava haridusseltsi tantsuõhtu orkestriga, on säilinud Viru-Nigulast. Pada kooli õpetaja (aastad 1909-1918) Kaarel Kruusimägi kirjutas oma mälestustes Viru-Nigula Haridusseltsi tegevusest ja seltsi korraldatud eeskavaga pidudest: Piletite hinnad olivad I pl. 50 kop., II pl. 35 ja III seisuplats 25 kop. Tantsu ajaks olid eri piletid 25-35 kop. Selle järele, kas mängis tantsuks harilik "lõõtsmoonik” või siis puhkpilliorkester (ETMM Mo 226, sü 9, lk 1).

Enne Teist maailmasõda hakkasid Virumaal moodi tulema bajaanid ja akordionid, mis mõnikord toodi Rootsist, eriti rannakülades. Tänapäeval on akordion kogu Eestis peamine harrastusmuusikute pill.

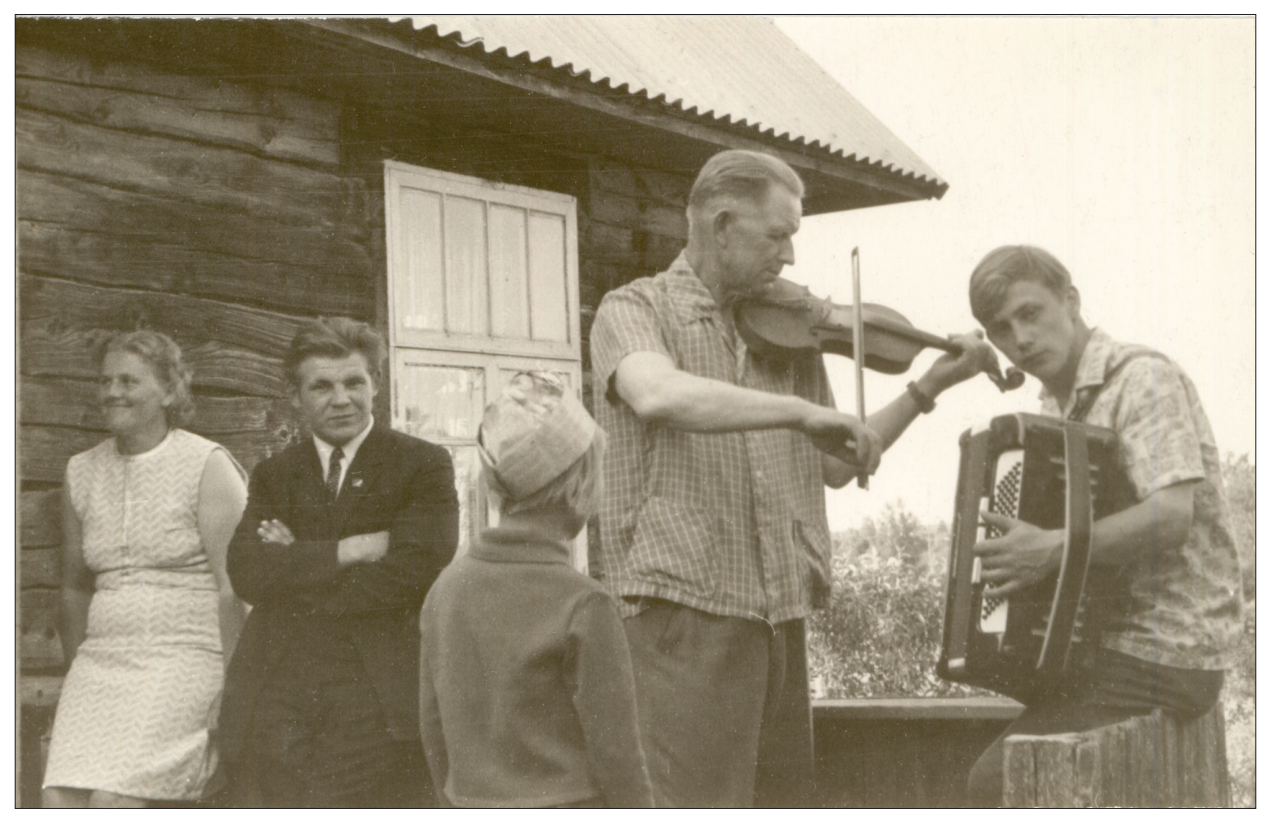

Foto 11. Pillimehed (Heinrich Masing pojaga) Kadrina khk, Kõrgemäe k jaaniõhtul. Mall Proodeli foto, 1969. ERA, Foto 8833. 
Virumaal traditsiooniliselt kasutatud muusikariistade ülevaate võiks lõpetada väljavõttega Haljalas üleskirjutatud regilaulust “Kündja põgeneb”. Laulus kirjeldatakse ülemeelikut rõõmupidu, mida põgeneja näeb metsa veerel. Kuna mujalt pole seda regilaulumotiivi Eestis fikseeritud, siis tunduvad need värsid Virumaal sündinud olevat:

Siis nägin vainul tantsuparved, metsa ääre mängutropid.

Sial oli viisi viiuliida, sial oli kaksi kannelida, tosin toista torupilli, enam muida musikanti.

(Vana kannel VI: 1, 1989: 371.)

\section{Arhiivilühendid}

\section{Ajaloo Instituudis (AI):}

AI ET - endise Ajalooinstituudi etnograafia sektori käsikirjaline etnograafiliste teadete kogu, mis asub nüüd Eesti Rahva Muuseumis

\section{Eesti Keele Instituudis (EKI):}

ES KT - Emakeele Seltsi korrespondentide tekstid

\section{Eesti Kirjandusmuuseumi (EKM) Eesti Rahvaluule Arhiivis}

\section{(ERA):}

E - Matthias Johann Eiseni rahvaluulekogu

EKRK - Tartu Ülikooli eesti kirjanduse ja rahvaluule kateedri rahvaluulekogu

ERA - Eesti Rahvaluule Arhiivi kogu

EÜS - Eesti Üliõpilaste Seltsi rahvaluulekogu

$\mathrm{H}$ - Jakob Hurda rahvaluulekogu

KKI - Keele ja Kirjanduse Instituudi rahvaluulekogu

RKM - Riikliku Kirjandusmuuseumi rahvaluulekogu

RKM, Mgn - Riikliku Kirjandusmuuseumi magnetofonilintide kogu 


\section{Eesti Rahva Muuseumis (ERM):}

ERM A - Eesti Rahva Muuseumi arhiiv

ERM EA - ERMi etnograafilise arhiivi käsikirjade kogu

ERM KV - ERMi korrespondentide vastused

\section{Eesti Teatri- ja Muusikamuuseumis (ETMM):}

ETMM Mo - Eesti Teatri- ja Muusikamuuseumi muusikaosakonna kogu

ETMM M - Eesti Teatri- ja Muusikamuuseumi muusika kogu

Pulst - Pulst, August. Mälestusi muusika alalt. Käsikiri Eesti Teatri- ja Muusikamuuseumis, 1960. aastad. M 234: 1.

\section{Virumaa Muuseumis (VM, SA Virumaa Muuseumid koosseisus asuva endise Virumaa Muuseumi kogu):}

VM E - Virumaa Muuseumi etnograafiline kogu

\section{Kirjandus}

Ariste, Erna 1934. Lokulaud. Eesti Rahva Muuseumi aastaraamat VIII. Tartu: Eesti Rahva Muuseum, lk 1-27.

Eesti rahvalaulud I = Eisen, Matthias Johann \& Krohn, Kaarle \& Alava, Vihtori \& Kallas, Oskar \& Anderson, Walter \& Grünthal-Ridala, Villem (toim) 1926. Eesti rahvalaulud. Esimene köide: dr. Jakob Hurda ja teiste kogudest = Estonum Carmina popularia. Volumen primum : ex d:ris Jacobi Hurt aliorumque thesauris. Eesti Kirjanduse Seltsi Toimetused 21. Tartu: Eesti Kirjanduse Selts.

Eisen, Matthias Johann 1925. Karjane. Eesti Rahva Muuseumi aastaraamat I. Tartu: Eesti Rahva Muuseum, lk 9-34.

Haas, Ain 2016. Rahvapillipärandi säilitamine Eestis ja välismaal. Mäetagused 63. Hüperajakiri. Tartu, lk 89-128 (http://www.folklore.ee/tagused/nr637haas.pdf - 2. veebruar 2017, doi: 10.7592/MT2016.63.haas).

Haasma, Urvi 1986 = Khaasma U. Estonskie naigryshi na koz'em roge. Riuitel, Ingrid (koost). Muzyka v obriadakh i trudovoi deiatel'nosti finno-ugrov. Tallinn: Eesti Raamat, lk 70-100.

Jaago, Cätlin 2011. Eesti parmupill. Helisalvestusi Eesti Rahvaluule Arhiivist 6. Tartu: Eesti Kirjandusmuuseumi Teaduskirjastus.

Kirme, Kaalu 1986. Eesti sõled. Tallinn: Kunst. 
Kõiva, Mare 1992. Loitsud ja rahvaarstid. Rüütel, Ingrid (koost, toim). Ida-Virumaa rahvakultuurist. Tallinn: AS Infotrükk, lk 117-131.

Lahemaa lugusid = Must, Mari (koost) 1989. Lahemaa lugusid . Tallinn: Eesti NSV Teaduste Akadeemia.

Leisiö, Timo \& Tainio, Juha 1988. "Pisti pillit säkkihinsä”. Ajatuksia säkkipillistä Suomenlahden rantamailla. Arkki 13. Tampere: Tampereen yliopisto, kansanperinteen laitos.

Loorits, Oskar 2001. Endis-Eesti elu-olu IV. Lugemispalu karjakasvataja elust. Tartu: Eesti Kirjandusmuuseum.

Loorits, Oskar 2004. Endis-Eesti elu-olu II. Lugemispalu metsaelust ja jahindusest. Tartu: Eesti Kirjandusmuuseum.

Olearius, Adam 1996. Täiendatud uus reisikiri Moskoovia ja Pärsia teekonna kohta, mis toimunud Holsteini saatkonna lähetamisel Vene tsaari ja Pärsia kuninga juurde... Saksa keelest tõlkinud, kujundanud ja eessõna: Ivar Leimus. Tallinn: Olion.

Pulst, August. Mälestusi muusika alalt. Käsikiri Eesti Teatri- ja Muusikamuuseumis, 1960. aastad. M 234: 1.

Rannap, Heino 1972. Muusika eesti perekonnas ja rahvakoolis. Tallinn: Eesti Raamat.

Regilaulik = Tedre, Ülo \& Tormis, Veljo (koost) 1975. Regilaulik. Tallinn: Eesti Raamat.

Rüütel, Ingrid 1992. "Ei saa tõusta toonelasta..." Rahvalaul ja -muusika Ida-Virumaal 20. sajandi alguses. Rüütel, Ingrid (koost). Ida-Virumaa rahvakultuurist. Tallinn: AS Infotrükk, lk 207-258.

Suits, Juhan 2004. Eesti sikusarvede ehitus ja heliread. Diplomitöö. Käsikiri. Viljandi: Viljandi Kultuuriakadeemia, Rahvamuusika õppetool.

Tampere, Herbert 1975. Eesti rahvapillid ja rahvatantsud. Tallinn: Eesti Raamat.

Teinbas, Taavi 1994. Lõõtspillidest, lõõtspillimängust ja -mängijatest. Tallinn: Eesti Rahvakultuuri Arenduskeskus.

Tõnurist, Igor 1985. Eesti ja Pihkvamaa etnomuusikalised suhted. (Rahvapillid). Emakeele Seltsi aastaraamat 31, Tallinn: Eesti Raamat, lk 98-107.

Tõnurist, Igor 1996a. Mollpill Eestis. Tõnurist, Igor. Pillid ja pillimäng eesti külaelus. Scripta ethnologica I. Tallinn: Teaduste Akadeemia Kirjastus, lk 127-137.

Tõnurist, Igor 1996b. Parmupill Eestis. Tõnurist, Igor. Pillid ja pillimäng eesti külaelus. Scripta ethnologica I. Tallinn: Teaduste Akadeemia Kirjastus, lk 114-126.

Tõnurist 1996c = Tõnurist, Igor. Pillid ja pillimäng eesti külaelus. Scripta ethnologica I. Ajaloo Instituut. Tallinn: Teaduste Akadeemia Kirjastus.

Tõnurist, Igor 2004. Setu sarvepilli lugu. Setumaa kogumik 2. Uurimusi Setumaa arheoloogiast, geograafiast, rahvakultuurist ja ajaloost. Tallinn: Ajaloo Instituut \& MTÜ Arheoloogiakeskus, lk 81-93.

Tõnurist, Igor 2007. Eesti idiofonid - traditsioon ja "juhuslikkus”. Kõiva, Mare (koost). Paar sammukest. Eesti Kirjandusmuuseumi aastaraamat XXIII (2006). Tartu: Eesti Kirjandusmuuseumi Teaduskirjastus, lk 273-324. 
Vana Kannel VI:1 = Laugaste, Eduard (koost) 1989. Vana kannel VI:1. Haljala regilaulud. Monumenta Estoniae antiquae. Tallinn: Eesti Raamat.

Vana Kannel VIII = Kokamägi, Hilja \& Tedre, Ülo \& Tuvi, Edna (koost) 1999. Vana kannel VIII. Jõhvi ja Iisaku regilaulud. Monumenta Estoniae antiquae. Tartu: Eesti Keele Instituut.

Viires, Ants 1959. Chr. H. Schlegeli "Reisen in mehrere Russische gouvernements" etnograafilise allikana. Etnograafia Muuseumi aastaraamat XVI. Tallinn: Eesti Riiklik Kirjastus, lk 249-274.

Viires, Ants 2003. Pillid ja pillimäng rahva keeles ja meeles. Keel ja Kirjandus 5, lk 362-365.

Igor Tõnurist - pensionil etnoloog ja rahvamuusik. Aastail 1995-2008 oli Lääne-Viru maakonnas kuuel korral rahvusvahelise folkloorifestivali Viru Säru kunstiline juht.

tonurist@hot.ee

\title{
Summary
}

\section{Folk instruments in Virumaa}

\author{
Igor Tõnurist
}

Keywords: aerophones, chordophones, folk instruments, idiophones, Iisaku poluvertsiks, membranophones, Virumaa

The article gives an overview of the traditional musical instruments and sound making devices of Estonian peasants in historical Virumaa, as well as their usage on the basis of data collected mainly in the 19th-20th centuries.

Folk instrument playing culture in Virumaa region is part of the common northEstonian folk music area, which covers Harju, Järva, and Viru counties. Undoubtedly, the idiosyncrasy of folk music in this area has mainly been shaped by the northern Estonian regilaul (runosong); yet, the relatively similar choice of traditional musical instruments is also characteristic. Local peculiarities of Virumaa stand out only in the case of a few phenomena, such as piibar (a flute-like whistle made of willow bark) and names for the newer type of psaltery (simmel/tsimmel/simbel). In the choice of instruments, their names, and repertoire the so-called Iisaku poluvertsiks' (Lutheran Russians) local folk instrument playing tradition can be distinguished, which mixes Russian and Estonian phenomena (incl., e.g., names of instruments: psaltery - kusli, jew's harp-vargan, willow whistle-dutka, drum - puuben). Russian villages on the northern coast of Lake Peipus and along the Narva River had their own explicit ethnic playing tradition. The northern coast of Virumaa had some common features also with Finnish folk instrument and folk dance traditions (influence in the repertoire of dance music, violin-playing, etc.), while at the lower course of the Narva River contacts occurred with local Izhorian herdsmen and their instruments (e.g. large herdsman's trumpet truba). 
Folk music instruments in Virumaa can be divided by their sound-making mode into wind instruments (e.g. clarinet-type and trumpet-type aerophones), string instruments (chordophones), idiophones, and membranophones.

The article approaches folk instruments in Virumaa on the basis of their main building indicators as well as spheres of usage, and their mentions in oral folklore.

Igor Tõnurist is retired ethnologist and folk musician. In the years 1995-2008 he was six-time artistic manager of the international folklore festival Viru Säru in Lääne-Viru County.

tonurist@hot.ee 